\title{
African Americans, Gentrification, and Neoliberal Urbanization: the Case of Fort Greene, Brooklyn
}

\author{
Themis Chronopoulos ${ }^{1}$ (D)
}

Published online: 28 September 2016

(C) The Author(s) 2016. This article is published with open access at Springerlink.com

\begin{abstract}
This article examines the gentrification of Fort Greene, which is located in the western part of black Brooklyn, one of the largest contiguous black urban areas in the USA. Between the late 1960s and 2003, gentrification in Fort Greene followed the patterns discovered by scholars of black neighborhoods; the gentrifying agents were almost exclusively black and gentrification as a process was largely bottom-up because entities interested in the production of space were mostly not involved. Since 2003, this has changed. Whites have been moving to Fort Greene in large numbers and will soon represent the numerical majority. Public and private interventions in and around Fort Greene have created a new top-down version of gentrification, which is facilitating this white influx. Existing black residential and commercial tenants are replaced and displaced in the name of urban economic development.
\end{abstract}

Keywords Black Neighborhood · Brooklyn · Fort Greene $\cdot$ Gentrification · Neoliberal Urbanization $\cdot$ New York $\cdot$ Race

\section{Introduction}

On February 25, 2014, in a Black History Month speech at Pratt Institute, after being prodded by an audience member, Spike Lee unleashed a verbal attack against gentrification. He focused on the impact of gentrification upon black New Yorkers, mixing personal experiences with those of black residents of Fort Greene:

Then comes the motherfuckin' Christopher Columbus Syndrome. You can't discover this! We been here. You just can't come and bogart. There were brothers playing motherfuckin' African drums in Mount Morris Park for 40 years and now they can't do it anymore because the new inhabitants said the drums are loud. My

Themis Chronopoulos

T.Chronopoulos@swansea.ac.uk

1 Swansea University, Swansea, Wales, UK 
father's a great jazz musician. He bought a house in nineteen-motherfuckin'sixty-eight, and the motherfuckin' people moved in last year and called the cops on my father. He's not-he doesn't even play electric bass! It's acoustic! We bought the motherfuckin' house in nineteen-sixty-motherfuckin'-eight and now you call the cops? In 2013? Get the fuck outta here! . . . When Michael Jackson died they wanted to have a party for him in motherfuckin' Fort Greene Park and all of a sudden the white people in Fort Greene said, "Wait a minute! We can't have black people having a party for Michael Jackson to celebrate his life. Who's coming to the neighborhood? They're gonna leave lots of garbage." Garbage? Have you seen Fort Greene Park in the morning? It's like the motherfuckin' Westminster Dog Show. There's 20,000 dogs running around. Whoa. So we had to move it to Prospect Park! (Coscarelli 2014).

Lee's emphasis on Fort Greene was not accidental. He grew up in the neighborhood and still has his production company there. In recent years, Lee has been witnessing a rapid racial transition from black to white in Fort Greene, which led him to the outburst at Pratt Institute.

Two days after Lee's speech, the New York Daily News published an article entitled "B'klyn Gentrifiers Respond to Spike Tirade: YOU WHINER" (Murphy 2014). In the article, a few Fort Greene residents expressed their disapproval of Lee's comments. Marina Rutherfurd who had recently moved from the Hamptons to Fort Greene to open a restaurant said that "I don't see a negative to cleaning up a neighborhood." Megan Feeney, who lived in a co-op that she bought two years before, claimed that she disagreed with the gentrification statements and that Lee "has the right to live wherever he wants to live, and people have the right to live wherever they want to live." Both of these residents were found by the newspaper reporter walking their designer dogs. Donna Yu, a jewel designer from Toronto, who operated a dog-walking service in order to make ends meet, argued that she benefits from gentrification and that the amount of business that she gets, allows her to have a "decent cup of coffee" (Murphy 2014). This article in which the reporter managed to only find people who disliked Lee's comments and supported gentrification, typifies a recent embrace of the process by the mass media (Buntin 2015; Davidson 2014; Hampson 2005; Nevius 2013; Sullivan 2014).

This embrace originated in the work of a few scholars who have been representing gentrification as a positive process. In 2004, Lance Freeman and Frank Braconi argued that poor households living in gentrifying neighborhoods of New York City during the 1990s were less likely to relocate than poor households living in other areas and viewed this as evidence that displacement in gentrifying neighborhoods was minimal (Freeman and Braconi 2004). This claim challenged one of the main principles in gentrification research, which emphasizes the displacement of low-income households by more affluent ones (Lees et al. 2007; Smith 1996; Stabrowski 2014). Tom Slater has found Freeman's work to be part of a recent provocative trend in scholarly literature that downplays the negative effects of gentrification (Slater 2006, 2009). This literature even insists that existing low-income residents benefit when their neighborhood gentrifies (Byrne 2002; Duany 2001; Freeman 2005, 2006, 2009; Vigdor 2002). In fact, Freeman and Braconi (2004) argue that neighborhoods can gentrify without any displacement as long as poor people who vacate housing units voluntarily are replaced by more affluent households. 
Gentrification actually goes beyond displacement and includes the replacement and exclusion of certain populations from a neighborhood. The replacement of low-income populations in a specific neighborhood by more affluent ones is not something natural or neutral but reveals antagonistic class relations based on geography. After all, this kind of replacement does not occur in most city neighborhoods. It occurs only in the neighborhoods that are gentrifying. More than this, under gentrification, the movement of people acquires it own exclusionary dynamics. Low-income people can no longer move to a gentrifying neighborhood, because they are priced out and because landlords and real estate entities are seeking a different type of tenancy. Peter Marcuse calls this process exclusionary displacement (Marcuse 1985).

Freeman (2006) researched Clinton Hill (the neighborhood east of Fort Greene) and compared it with Harlem. Freeman found that existing residents resented the fact that their neighborhoods had to attract whites before the city government provided decent municipal services and infrastructural improvements. At the same time, Freeman found that many existing residents were not unhappy with the changes taking place in their neighborhoods and appreciated improvements.

In my research, most existing residents did not express as much appreciation about the changes. They recognized that Fort Greene was doing better in infrastructural and material ways, even though their cost of living had become more expensive. However, they also acknowledged that these improvements had come at a great cost that went beyond economics. This cost included the departure of many of their friends and relatives, a decline of a cultural and commercial infrastructure that they cherish, and the fear that they themselves would one day have to leave a neighborhood that they view as their home (Ethnographic Research 2005, 2011). While the new white residents that I encountered enjoyed the black cultural infrastructure, they approached it in a detached way. It made no difference to them whether the restaurant next door served South African, French, or Southern food. They usually preferred the types of establishments that they had encountered in college or in majority white urban areas, though they also did not mind the offerings of Fort Greene (Ethnographic Research 2011).

\section{Literature Review}

While gentrification has generally been defined as a class relationship based on space, in cities located in the USA, race is as important. When the gentrification of black neighborhoods became identifiable in the 1980s, scholars claimed that this was temporary because many African Americans lacked the financial ability to purchase or rehabilitate homes (Schaffer and Smith 1986). This expectation turned out to be false. Moreover, early studies emphasized homeownership as an important element of gentrification and discovered that both white and black homeowners displaced or replaced less affluent black renters (Spain 1980; Wilson 1992). Looking at the 50 largest metropolitan areas in the USA, Raphael W. Bostic and Richard W. Martin found that black homeowners had a gentrifying influence in the 1970s but not in the 1980s (Bostic and Martin 2003). Although these studies are important, homeownership is not the litmus test of gentrification. Especially in large American cities such as New York, Los Angeles, and Chicago, the majority of residents are renters and gentrifying neighborhoods comprise of majority renter households. Moreover, in most cities, gentrification 
occurs at the neighborhood level, which means that the larger the area examined, the more likely to discover no gentrification patterns. For example, in New York City, median household incomes have stagnated since the 1990s and the proportion of whites has been declining for most of the post-1945 period. However, in gentrifying neighborhoods in New York, incomes have been increasing and along with them the numbers of whites.

Most studies of black gentrification have focused on New York City with Central Harlem being the most researched neighborhood (Hoffman 2003; Jackson 2001; Prince 2002, 2005; Smith 1996; Taylor 1992, 2002; Zukin et al. 2009). This is not surprising given Harlem's historical status as the epicenter of black political and cultural life in the USA. At the same time, Central Harlem has been a low- to moderate-income neighborhood with a large number of public and subsidized housing units. Moreover, Central Harlem is located in an area that has not experienced intense gentrification pressures until recently. Fort Greene is different from Harlem in the sense that sections of it became middle class earlier and gentrification there has been more pronounced. For example, median household incomes in Fort Greene are significantly higher from those of Central Harlem (Fig. 1). So is the percentage of people performing professional and managerial tasks (Fig. 2).

In recent years, scholars have diversified their research on black gentrification and included neighborhoods in Chicago, Philadelphia, and Washington, DC. Michelle Boyd shows how black gentrification in the Douglas/Grand Boulevard section of Chicago was encouraged as a strategy of "uplifting the race" and preventing gentrification by whites (Boyd 2005, 2008). Derek Hyra argues that the economic revitalization of Bronzeville in Chicago and Harlem mirrors past urban renewal projects because of the use of federal resources and the displacement of low-income households (Hyra 2008). Kesha S. Moore demonstrates how the black gentrifiers of Brickton, a low-income African American neighborhood in Philadelphia, see their investments in the community as ways to reverse historic and contemporary forms of racism (Moore 2005, 2009). In general, scholars

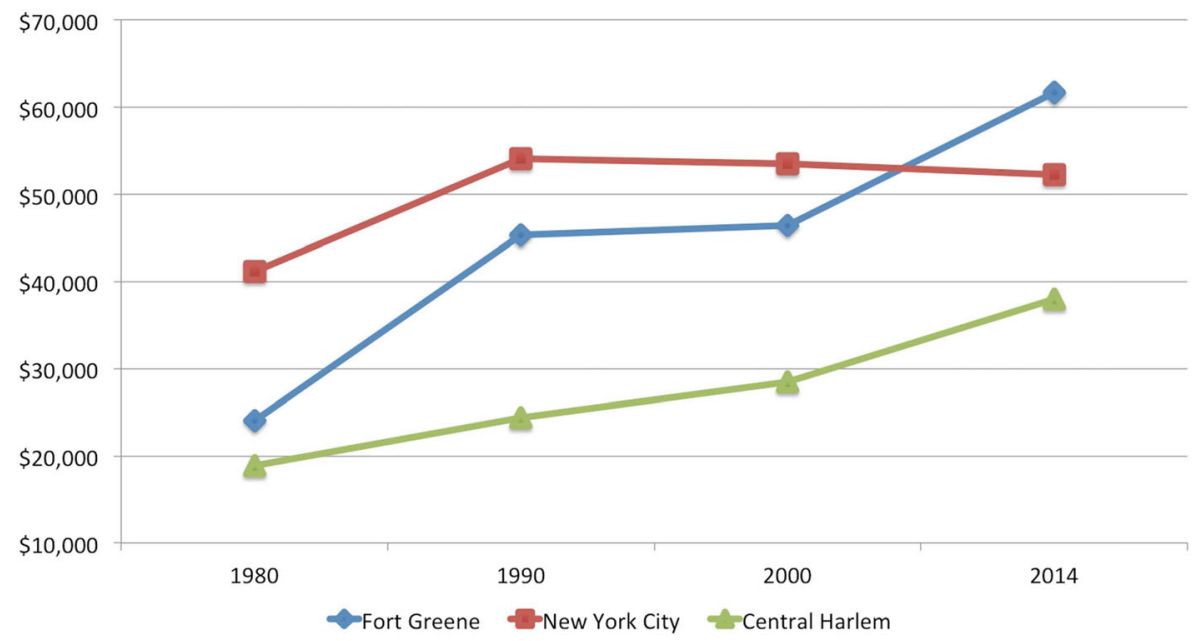

Fig. 1 Median household income in Fort Greene, New York City, and Central Harlem, 1980-2014. Source: U.S. Census Bureau Surveys, 1980-2000, and the Five-Year American Community Survey, 2014 


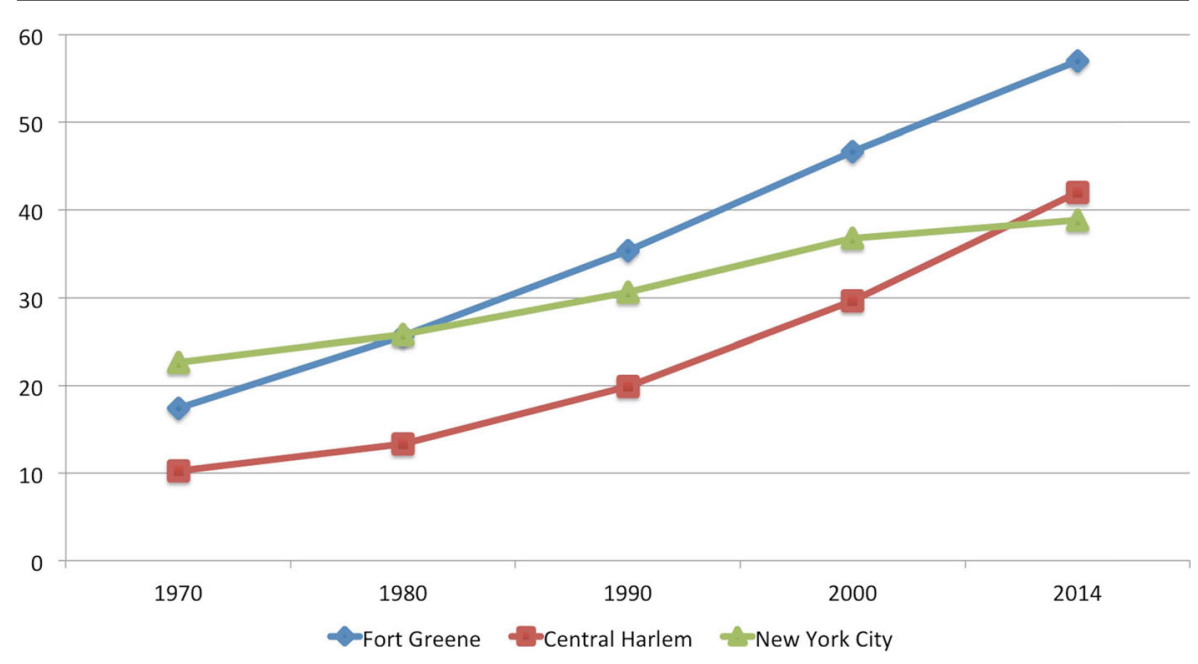

Fig. 2 Percentage of people performing managerial and professional specialty occupations in Fort Greene, Central Harlem, and New York City, 1970-2014. In Fort Greene, this percentage approximated $60 \%$ in 2014. In Harlem, it was $42 \%$. Source: U.S. Census Bureau Surveys, 1970-2000, and the Five-Year American Community Survey, 2014

studying the gentrification of black neighborhoods have argued that the gentrifying agents are black rather than white (Boyd 2005, 2008; Hyra 2008; Jackson 2001; Moore 2005, 2009; Pattillo 2007; Taylor 2002). Although the argument that black neighborhoods are gentrified by black people is largely accurate, recent changes occurring in Washington DC and New York reveal new patterns.

In Washington, DC, these changes are profound in the sense that a majority black city is becoming white for the first time in many decades (Hyra and Prince 2016). The replacement and displacement of blacks by whites in Washington, DC, has been documented since at least the 1980s (Williams 1988), though the process has accelerated in the twenty-first century; many black neighborhoods are currently becoming white and more affluent. Washington, DC, has disproportionately been influenced by the growth of the federal government and the expansion of industries associated with it. Well-educated professionals and managers have been moving to the city in large numbers in order to work for the federal government, lobbying agencies, the courts, the media, NGOs, labor unions, and all kinds of national and international organizations. Most of these people are white. Despite efforts by the city government, which in the 1970s enacted one of the most sweeping anti-displacement legislations, to slow down gentrification pressures, the immensity and power of the latest gentrification wave has swept away many of the people who were previously able to stay put (Asch and Musgrove 2016; Heck 2016; Howell 2016; Hyra 2015).

In New York City, the displacement or replacement of blacks is not as extreme as that of Washington, DC. This is because New York is a significantly larger city and its black population has not been declining for decades as in Washington, DC. ${ }^{1}$ However, whites

\footnotetext{
${ }^{1}$ The population of Washington, DC, is approximately 650,000 people. However, the immense size of the federal government and ancillary entities create a spatial dynamic for these 650,000 people that is difficult to replicate elsewhere.
} 
have recently moved to some black neighborhoods in large numbers and this is a phenomenon that requires serious study. In general, the white gentrification of black neighborhoods in New York depends on the class nature of these neighborhoods, their proximity to central parts of the city, their cultural and commercial infrastructure, the desirability of proximate neighborhoods, the easy access to mass transit, as well as their built environment (existing and newly built). Fort Greene is attractive because it possesses all of these attributes. Still, without the acceleration of the process of neoliberal urbanization under which the public and private sectors began to redevelop Fort Greene and its surroundings during the twenty-first century, the racial transition of the area may not have been as extreme.

Taking a longer historical perspective, this article examines the dynamics of gentrification in Fort Greene, Brooklyn. It builds on the work of scholars who study black gentrification (Boyd 2005, 2008; Hyra 2008; Jackson 2001; Moore 2005, 2009; Pattillo 2005, 2007; Taylor 2002) in the sense that between the late 1960s and the early 2000s, gentrification in Fort Greene followed the patterns of most other black neighborhoods in the USA; the great majority of middle class newcomers were black. The article is also sensitive to the cultural tendencies of people who lived in Fort Greene by using George Lipsitz's concept of the black spatial imaginary - the idea of community control by lowincome blacks as the best way to advance neighborhood interests (Lipsitz 2011). As middle class blacks gentrified Fort Greene, the radical version of the black spatial imaginary was moderated and replaced by a more mainstream vision of urban affairs.

This article is different from many works on black gentrification in the sense that the gentrification of the twenty-first century involved mostly white people. Under the guise of color blindness (Bonilla-Silva 2006), the public and private sectors facilitated this new and more intense version of gentrification; the result was the large influx of affluent white newcomers who replaced or displaced mostly black people. With the exception of contemporary studies about neighborhood change in Washington, DC (Hyra and Prince 2016), this new development in the gentrification of black neighborhoods like Fort Greene under which whites are moving there in large numbers has not been studied by scholars of black gentrification, mostly because it is a very recent phenomenon occurring in a few neighborhoods and cities in the USA. However, this development, which admittedly is still the exception, appears to be accelerating and this raises a number of questions about the racial implications of gentrification, the politicaleconomic structure of society, and the role of the government in urban development.

\section{Project Design}

This article discusses gentrification in Fort Greene, Brooklyn. The period examined is between 1960 and 2014. Fort Greene contains census tracts 29.01, 29.02, 31, 33, 35, 179, 181, 183, 185.01, 185.02, and 187 of Kings County of New York (Fig. 3). In this sense, the census tracts define the boundaries of Fort Greene and while they may slightly deviate with boundaries stated in other sources, there is no such thing as exact neighborhood boundaries in New York City. Before the 1980s, Clinton Hill was also considered to be part of Fort Greene (Habenstreit 1974; Rosenberg 1998). Unless necessary, Clinton Hill is not included in this study, because Fort Greene has its own neighborhood dynamics and has been identified as a separate entity in the last 35 years or so. 


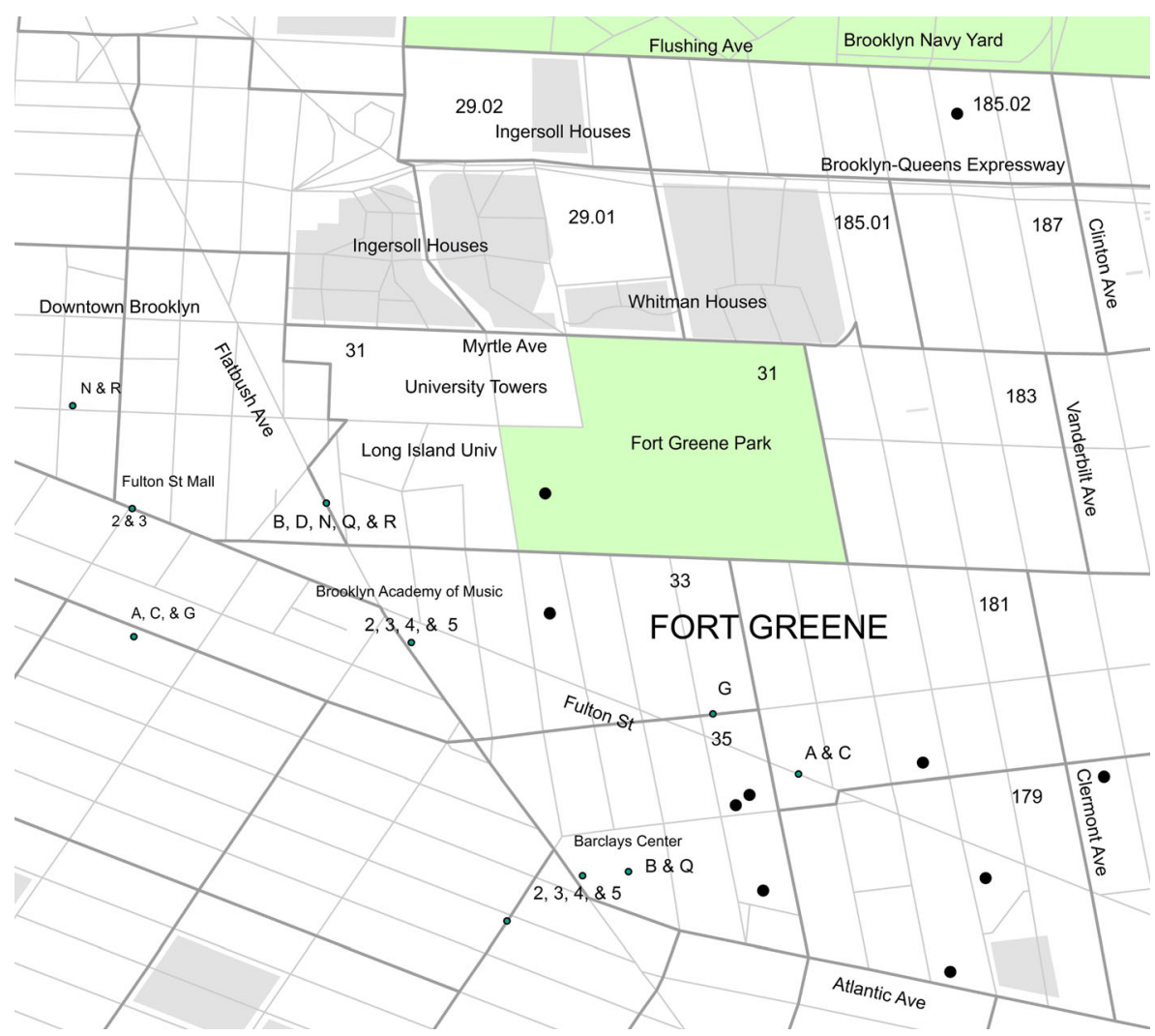

Fig. 3 Map of Fort Greene, Brooklyn. The number of each census tract is located on the top right of each tract. Public housing is indicated in the shadowed areas. The black dots represent subsidized housing buildings as of 2014. Subway stations and their lines are also displayed. Source: Map created by the author

The northern part of Fort Greene is occupied mostly by public housing (Fig. 3). The Fort Greene Houses, which consist of 35 buildings, were completed during World War II in order to house Brooklyn Navy Yard workers. In the postwar period, the Fort Greene Houses were predominantly occupied by African Americans. The mass media regularly reported on this largest public housing project in New York, highlighting problems associated with juvenile delinquency, maintenance problems, and crime. Because of this, the New York City Housing Authority paid lots of attention to the Fort Greene Houses at the expense of other housing projects (Bloom 2008). In 1972, the Fort Greene Houses were separated into the Walt Whitman and Raymond V. Ingersoll Houses. Census tracts 29.01, 29.02, and 185.01, which are occupied almost exclusively by these public housing projects, are not gentrifying.

The area of Fort Greene outside of public housing has been gentrifying since the late 1960s. This area is known for the large number of brownstones, though many apartment buildings and condominiums are also located there. It consists of census tracts 31 , 33, 35, 179, 181, 183, and 185.02, and 187 (Fig. 3).

My methodology includes spatial analysis accompanied by the reading and making of maps; interviews, conversations, and observations recorded in notebooks; the photographing of key aspects of the neighborhood and the subsequent cataloging and 
studying of the photographs; the reading of primary and secondary writings about Fort Greene; and the use of quantitative data in order to illuminate upon demographic shifts. I originally planned to write an article based on the findings of the ethnographic research, though I eventually concluded that census data would enhance my findings and strengthen my portrait of the neighborhood.

Ethnographic research occurred in 1998, 2005, and 2011. This research was based on snowball sampling, and each time that it occurred, there was an effort to find new respondents in order to diversify existing accounts. The research went beyond the boundaries of Fort Greene and included Clinton Hill (located immediately east of Fort Greene) and the western part of Bedford-Stuyvesant (located immediately east of Clinton Hill). After respondents in 2005 emphasized the end of Fort Greene as a black neighborhood and after witnessing the closure of numerous stores owned by blacks, I decided to wait and to complement my study with quantitative research.

The statistics presented in this article are derived from the U.S. Census Bureau's decennial surveys of 1960, 1970, 1980, 1990, 2000, and 2010 as well as the Five-Year American Community Survey of 2014. The 2014 Five-Year American Community Survey includes the average of the 2010-2014 period. It is currently viewed as the most up-to-date survey. Unless otherwise stated, monetary figures that refer to individuals and households are adjusted for inflation to 2014 U.S. dollars using the Consumer Price Index of the Bureau of Labor Statistics.

\section{Planning Policy and Socioeconomic Changes in Fort Greene, 1945-1980}

In the postwar period, Fort Greene became the western part of black Brooklyn, which is the largest contiguous black area of New York City (Connolly 1977; Pritchett 2002; Thabit 2003; Wilder 2000; Woodsworth 2016). Black Brooklyn included neighborhoods such as Clinton Hill, Bedford-Stuyvesant, Brownsville, East New York, Prospect Heights, Flatbush, East Flatbush, and Crown Heights. Fort Greene became majority black in the 1960s (Fig. 4), when the exodus of white ethnics (with a high proportion of Italians) accelerated because of deindustrialization and racial succession. Articles and reports lamenting the decline of Fort Greene from one of the most desirable sections of Brooklyn to a "slum" dominated public discourse in the decades following World War II and this had much to do with the area's racial turnover (Freeman 1958; Fried 1966; New York Times 1953).

During this period, slum clearance and urban renewal became the preferred methods to turn around areas designated as slums and modernize the city (Bloom 2008; Caro 1974; Schwartz 1993). City powerholders assumed that slum clearance would eliminate both the unwanted physical environment of a neighborhood and the people who lived in it. Minority areas located in central parts of the city were particularly targeted under slum clearance, though the results were not always those desired (Chronopoulos 2011a, 2014). In Fort Greene, slum clearance as a way of ordering the neighborhood and maintaining its whiteness failed early on. By the 1950s, the Fort Greene Houses and the Farragut Houses (located north of Fort Greene) - structures built under the expectations of urban renewal-were mostly occupied by low-income African Americans (Habenstreit 1974). Whites also moved to these public housing structures but in smaller numbers partly because of income requirements and partly because they did not want to live in 


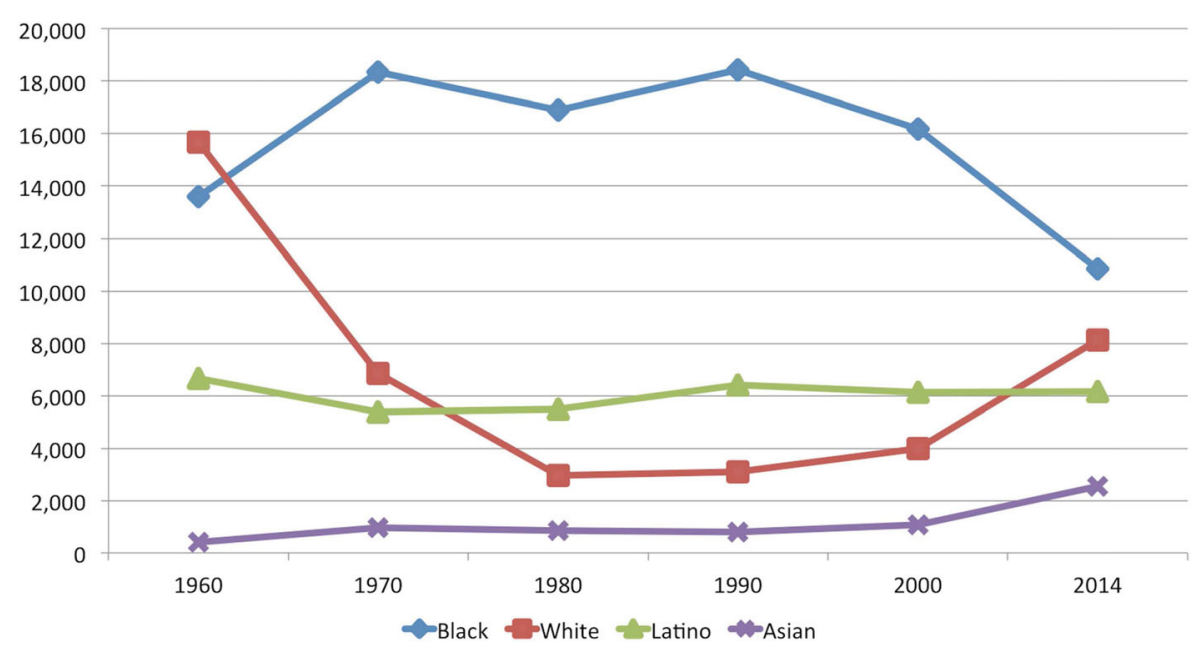

Fig. 4 Racial and ethnic groups in Fort Greene, 1960-2014. Source: U.S. Census Bureau Surveys, 19602000, and the Five-Year American Community Survey, 2014

developments with a high proportion of blacks. In fact, the numbers of African Americans living in the Fort Greene and Farragut Houses were so large that they began to dominate the shopping areas of downtown Brooklyn, which is adjacent to Fort Greene.

City officials became especially sensitive about the future of commercial centers such as downtown Brooklyn once they became spaces dominated by African Americans. ${ }^{2}$ While Fulton Mall and its environs (located west of Fort Greene) represented the second busiest commercial district of New York, city officials were not satisfied with its transition to a black space (Woo et al. 2010). The cultural and commercial infrastructure located in the three major commercial thoroughfares of Fort Greene and Clinton HillFulton Street, DeKalb Avenue, and Myrtle Avenue - blended into downtown Brooklyn and featured a vibrant nightlife increasingly dominated by black patrons and operators (Ethnographic Research 1998). The majority of these establishments were working class. Reports that these businesses were drug, gambling, and prostitution havens were greatly exaggerated (Sutton 2010). Critics of this cultural and commercial infrastructure were more interested in eliminating it rather than making it conform to legal statutes.

City planner Robert Moses decided to transform downtown Brooklyn from a retail, factory, and cultural zone into a civic center dominated by universities, hospitals, and other mainstream institutions (Schwartz 1993). Plans to redevelop downtown Brooklyn spilled over to Fort Greene with regularity and consumed sections of the neighborhood such as the western part of Fort Greene Park. In fact, it appeared easier to redevelop Fort Greene rather than downtown Brooklyn because city officials lacked a vision over the future of the downtown area and because too many powerful interests collided slowing down development. In the end, these efforts to transform downtown Brooklyn and portions of Fort Greene failed. Moses left his powerful and controversial position as construction coordinator in 1959 (Zipp 2010) and community opposition slowed down this type of urban

\footnotetext{
${ }^{2}$ Times Square is another such space. In fact, given its high profile status, efforts to order Times Square involved most city administrations in the twentieth century (Chronopoulos 2011a, b; Delany 1999; Reichl 1999).
} 
development (Angotti 2008). A portion of downtown Brooklyn that included the southwestern portion of Fort Greene was cleared after numerous delays in the early 1970s (Weisman 1971) though nothing was built before the 1990s (Curran 1998).

While Fort Greene was depicted as a "ghetto" with social problems such as juvenile delinquency, crime, poverty, and urban blight (Habenstreit 1974), it was also an inexpensive part of brownstone Brooklyn. Brownstone Brooklyn has traditionally encompassed neighborhoods such as Brooklyn Heights, Boerum Hill, Clinton Hill, Cobble Hill, Park Slope, Prospect Heights, and Carroll Gardens. Beginning in the 1960s, white middle class families moved to brownstone Brooklyn becoming homeowners and resisting city government redevelopment projects that viewed vast portions of Brooklyn as slums that were subject to clearance (Osman 2011). To be sure, it was not only brownstones that attracted white middle class newcomers to brownstone Brooklyn but also its relative whiteness.

The brownstone section of Fort Greene began to gentrify in the late 1960s, even if this gentrification before the 1980s was not as intense. The number of people performing professional and managerial occupations in Fort Greene declined from 1848 in 1960 to 1605 in 1970 . It increased to 2089 in the 1970 s and people performing such occupations in Fort Greene comprised $25.6 \%$ of the working population (Fig. 2). This percentage was higher from that of most working class neighborhoods in New York at the time. The percentage of lower middle class people performing office and sales occupations increased even more during this period reaching the $35.7 \%$ figure by 1980 (Fig. 5). Lower middle class people could still make a decent living in New York at the time and Fort Greene was an excellent neighborhood for them.

The racial trajectory of Fort Greene was markedly different from most of brownstone Brooklyn. The great majority of gentrifiers were black and not white. Although some white families also moved to Fort Greene because of its bargain housing prices, they represented the great exception. The discourses surrounding Fort Greene as a black ghetto and a slum dissuaded people unfamiliar with the dynamics and specificities of black neighborhoods from moving there. Between 1960 and 1980, the number of whites in Fort Greene actually declined by $81.1 \%$ (Fig. 4).

\section{The Black Spatial Imaginary in Brooklyn}

Building on his work on whiteness (Lipsitz 2006), George Lipsitz argues that "the white spatial imaginary views space primarily as a locus for the generation of exchange value" (Lipsitz 2011). In that sense, houses are investments whose value appreciates with the passage of time while the tax code benefits homeowners, contributing to higher home prices. The white spatial imaginary depends on racial segregation, since the influx of certain groups viewed as non-white has the potential of undermining real estate values (Freund 2007; Sugrue 1996).

Lipsitz (2011) juxtaposes the white spatial imaginary with the black spatial imaginary. He argues that the white spatial imaginary is not as useful for blacks, because racial segregation and other factors have compromised their ability to purchase homes. Instead, alternative conceptions of space have taken root in black communities, which treasure black neighborhoods, partly because of necessity and partly because of an attachment to place that goes beyond exchange value. Lipsitz emphasizes the 


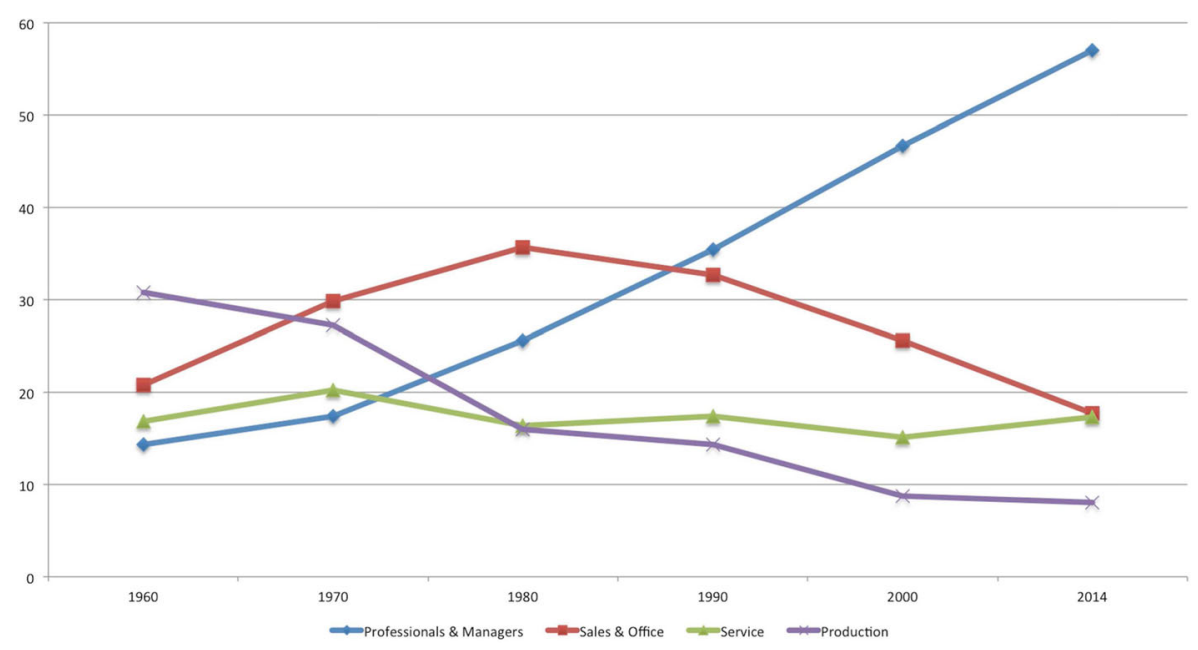

Fig. 5 Percentage of people by occupation in Fort Greene, 1960-2014. The percentage of professionals and managers has been steadily increasing since 1960. All other occupations stagnated or declined after 1980. Source: U.S. Census Bureau Surveys, 1960-2000, and the Five-Year American Community Survey, 2014

expressive cultural elements of the black spatial imaginary, but the concept also manifests itself socially and politically; through the formation of community and social movement organizations, black people have mobilized for the improvement of their neighborhoods and made claims for the availability of affordable local housing, accessible public health, efficient transportation systems, decent schools, and equitable municipal services.

In black Brooklyn, the black spatial imaginary took hold in the postwar period and is associated with the black freedom movement. Blacks living in the neighborhoods of black Brooklyn mobilized politically and gradually insisted on the community control of urban spaces. They rejected top-down government interventions such as slum clearance and urban renewal and believed that they could create a self-sufficient and independent urban world dominated by low-income blacks.

The black freedom movement of Brooklyn gained strength in the 1960s (Purnell 2013) when the black population of the borough almost doubled. During this period, political, religious, and community organizations became involved in grassroots organizing, seeking to win local elections, antagonize Brooklyn's hostile Democratic political machine, and rally for civil rights causes (Thompson 2006). These organizations challenged housing discrimination, boycotted local businesses that refused to hire minorities, protested inadequate sanitation provision, confronted the discriminatory employment practices of the building and construction trade unions, demanded the end of public school segregation and student overcrowding, and eventually tried to control and improve schools in black neighborhoods (Purnell 2013; Taylor 1994, 1997). While most of these mobilizations encountered firm opposition and had mixed results, the failure of the local community board to control the Ocean Hill-Brownsville school district after a confrontation with the United Federation of Teachers in 1968 (Podair 2008) is widely viewed as the end of the black freedom movement in Brooklyn. 
The assumption that Brooklyn's black freedom movement unceremoniously ended in 1968 is largely inaccurate. A new generation of black nationalist activists led by Al Vann, the former president of the Afro-American Teachers' Association, emerged. Vann ran as an independent for the state assembly and lost in 1972, but was successful in 1974. In the 1970s, he organized a number of black insurgencies in central Brooklyn against the borough's Democratic machine (Thompson 2006). By the 1980s and after civil rights litigation, Vann's organization had helped to elect a number of black politicians. These political successes were based on the black spatial imaginary, the idea that low-income blacks would get together and rebuild their neighborhoods in Brooklyn. Political power represented an important avenue toward this goal (Kim 2000).

Besides protest actions and political organizing, community groups and organizations surfaced in the late 1960s and early 1970s in Fort Greene in order to minimize displacement from downtown development and the revitalization of brownstones (Rosenberg 1998). During this period, the Fort Greene Housing Office was established and acted as a community development corporation (CDC) that sought to minimize the displacement of low-income residents through various programs that included the rehabilitation and allocation of city-owned buildings. Another organization was the Brooklyn Comprehensive Corporation, which initially focused on community gardening and eventually became a successful CDC, receiving public money and allying with private developers (DeGiovanni 1984). The Fort Greene Landmarks Preservation Committee sought to prevent the further clearance of the area and successfully lobbied the city government in 1978 to designate portions of Fort Greene as a historic district (New York City Landmarks Preservation Commission 1978). Other organizations included the Atlantic Terminal Urban Renewal Coalition, the Fort Greene Community Action Network, and the Fort Greene Strategic Neighborhood Action Partnership (Rosenberg 1998).

The heyday of the black spatial imaginary in Fort Greene was between the 1960s and early 1980s. In the postwar period, as whites were withdrawing from the area, blacks viewed Fort Greene as their neighborhood and most of them embraced a version of community control. Black Muslim stores opened up around the neighborhood and most other stores were also owned and operated by black people (Habenstreit 1974; Sutton 2010). Moreover, the employees of the supermarkets of the area were racially integrated, though this requires qualification. Finast had been racially integrated for a while and was viewed as a friend of the community. A\&P did not fully integrate even after boycotts by Operation Breadbasket, a Chicago organization of Reverend Jessie Jackson, that began operating in Brooklyn in the late 1960s under the leadership of Reverend William Jones (Taylor 1994). The boycotts failed, but the shooting of a man by a security guard in the A\&P located on Myrtle Avenue in Fort Greene forced the store to racially integrate more. Still, many local residents refused to shop there (Habenstreit 1974).

The black spatial imaginary of Fort Greene was eventually compromised. The 1970s was one of the worst decades in the history of New York City, which lost $10.4 \%$ of its population. Fort Greene also shrunk with many of its residents relocating elsewhere (Fig. 6), though the biggest problem that the area faced was a decline of its working class cultural and commercial infrastructure. Many stores closed because there were fewer customers without much disposable income. By the 1980s, a larger number of middle class blacks moved to Fort Greene and new stores and institutions arose in order to serve them. However, these new residents and the cultural infrastructure associated with them had a different conception of 


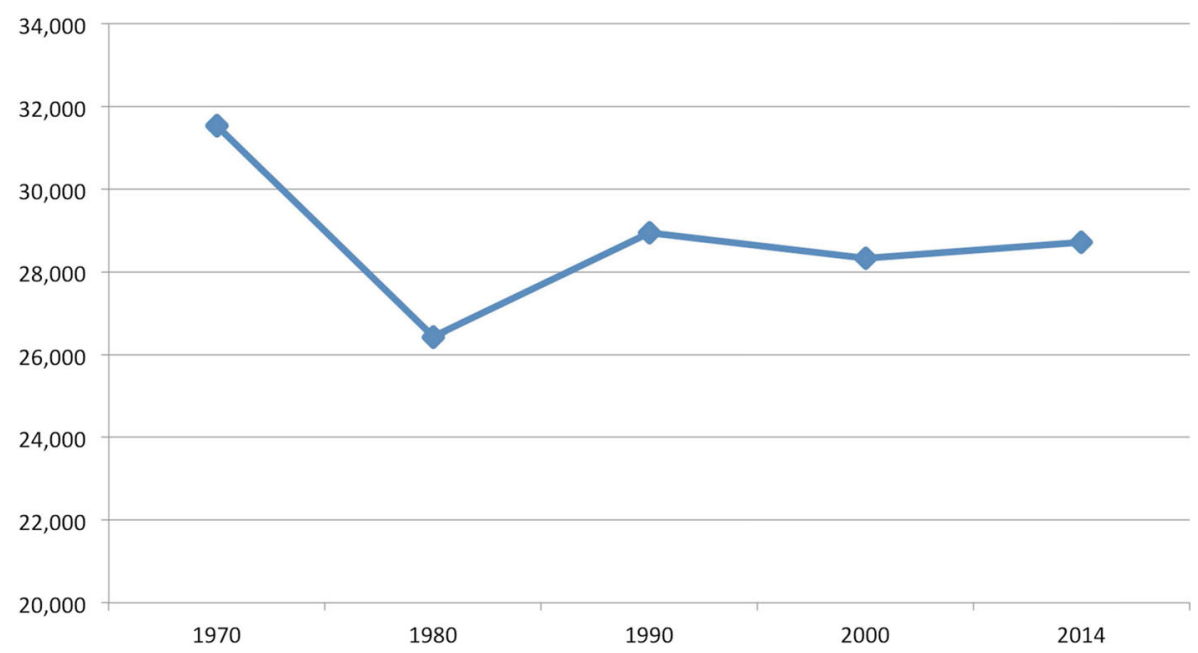

Fig. 6 Population of Fort Greene, 1970-2014. After a rapid decline in the 1970s, the population of Fort Greene began to increase. However, these increases were lackluster after 1990. Gentrification does not imply the increase of a neighborhood's population, especially when the construction of new housing is minimal. Source: U.S. Census Bureau Surveys, 1970-2000, and the Five-Year American Community Survey, 2014

community control that was less radical. The black middle class newcomers wanted decent housing, quality schools, adequate municipal services, and a fair allocation of government resources. They also wanted the neighborhood to remain black. At the same time, they did not necessarily support public housing, squatting, rooming houses, working class establishments, alternative lifestyles based on limited resources, or radical political ideas and organizations (Ethnographic Research 1998). The black spatial imaginary persisted in parts of black Brooklyn east of Fort Greene and Clinton Hill in communities that maintained their working class character.

\section{The Making of a Black Middle Class Neighborhood, 1980-2000}

In the mid-1980s, a black manager of a multinational corporation who had recently moved with his family to Fort Greene went to pick up his child from a birthday party, taking place near his house. He realized that most of the parents of the other kids, some of whom he knew, also had college education and held professional or managerial jobs. Of course, there were also parents who were paralegals or clerical workers, but these people also belonged to the middle class broadly defined. This encounter confirmed to this manager what he already recognized that this was a black middle class neighborhood. Indeed, Fort Greene was a far cry from the low-income area that he had grown up in the Midwest. When I interviewed Fort Greene residents in the late 1990s, stories like the one of the manager encountering large numbers of other middle class people proliferated widely (Ethnographic Research 1998). And these stories may sound ordinary, but in the 1980s, the concept of an urban black middle class neighborhood was not as common. 
The number of professionals and managers in Fort Greene increased by $90.4 \%$ in the 1980s and an additional $34.2 \%$ in the 1990s (Fig. 2). By 2000, professionals and managers comprised $46.7 \%$ of the working population of Fort Greene. In the areas without public housing, median household incomes increased by $86 \%$ in the $1980 \mathrm{~s}$ and another $6.5 \%$ in the 1990s. With the exception of managers and professionals, almost every other occupation category stagnated or declined in Fort Greene (Fig. 5). The drop in the number of people performing lower middle class jobs such as sales and office occupations indicated that Fort Greene was becoming a solidly middle class neighborhood with some upper-middle income families.

The middle class families were joined by younger single people, mostly African Americans (Ethnographic Research 1998). These groups lacked the economic capital of professionals and managers but had cultural capital and college education (Aalbers 2011; Bridge 2003; Moore 2009; Van Criekingen and Decroly 2003). People between the ages of 18 and 34 in the areas of Fort Greene without public housing increased from $30.8 \%$ of the population in 1970 to $38.5 \%$ in 1990 (Fig. 7). The percentage of this group in other gentrifying areas of New York such as the East Village was higher (Ethnographic Research 2011); however, Fort Greene had a higher percentage of owner-occupied housing units and a higher percentage of middle class families than the East Village. In fact, during the 1990s, the influx of young people slowed down in Fort Greene, because the neighborhood was already becoming expensive.

The proportion of owner-occupied housing units increased in Fort Greene during this period, though the great majority of housing units remained rentals. In the area without public housing, owner units went from $14.8 \%$ of total occupied housing in 1980 to $24.3 \%$ in 2000 (Fig. 8). The additional owner units originated from three sources: the first was conversions of existing rental apartments into owner units; the second was the subdivision and sale of portions of brownstones; and the third was the new construction of some condominiums. Still the majority of housing units in Fort

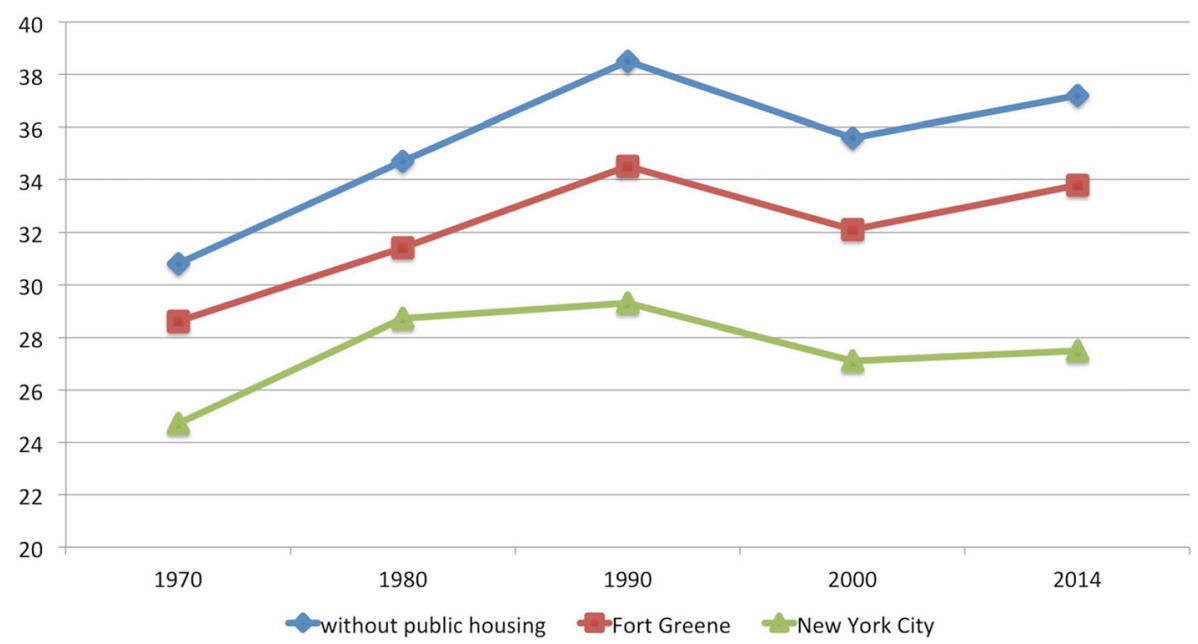

Fig. 7 Percentage of people between the ages of 18 and 34, in Fort Greene, the Fort Greene areas without public housing, and in New York City, 1970-2014. Source: U.S. Census Bureau Surveys, 1970-2000, and the Five-Year American Community Survey, 2014 


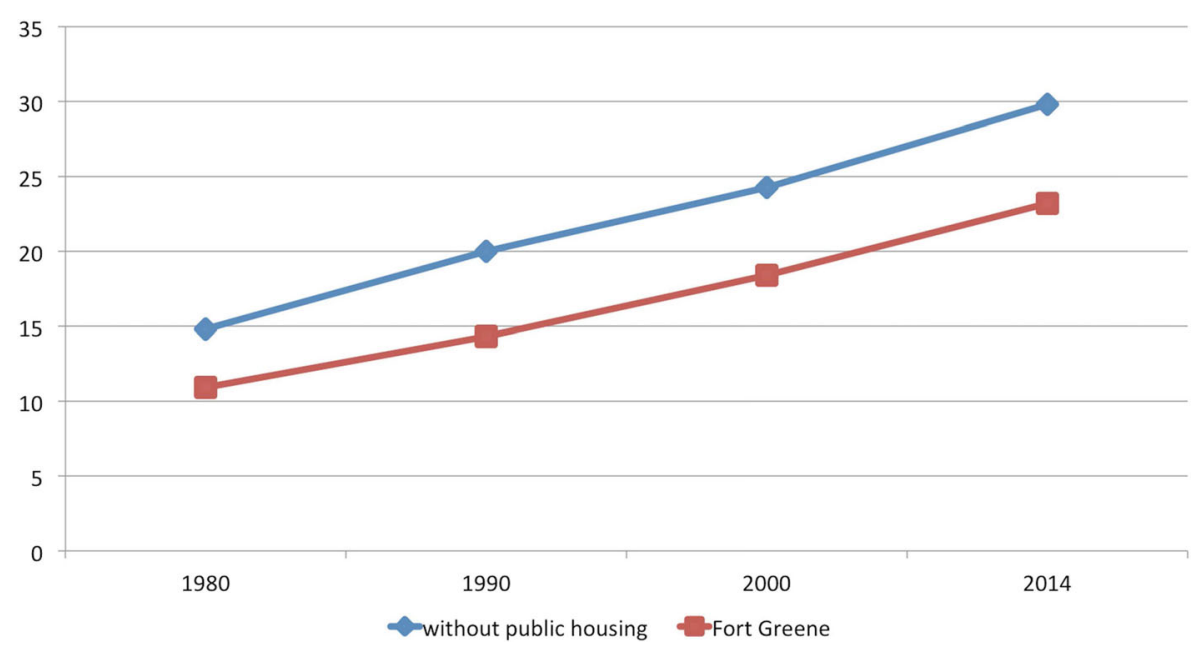

Fig. 8 Owner-occupied housing units in Fort Greene and in the area of Fort Greene without public housing, 1980-2014. Source: U.S. Census Bureau Surveys, 1980-2000, and the Five-Year American Community Survey, 2014

Greene were rentals. These rentals came in larger apartment buildings, public housing, as well as subdivided brownstones. The idea that families occupied brownstones in their entirety may have been popular (Fig. 9), but gradually these brownstones were subdivided and the apartments were rented or sold (Ethnographic Research 2005).

The middle class newcomers replaced or displaced mostly low-income residents. In the late 1970s and the 1980s, there were many evictions of people occupying brownstones that had been converted into rooming houses. These brownstones were reconverted into townhouses or into larger apartment units (Rosenberg 1998). As time went on, new occupants continued to replace older residents and housing became more expensive. By the late 1980s, a large proportion of lower middle class families began to also move away from Fort Greene and eastward in black Brooklyn seeking lower housing costs. Some of them were able to become homeowners in areas like Crown Heights or Flatbush, while others took advantage of subsidized owner housing units offered through city and state housing programs (Ethnographic Research 1998). Median gross rents in the areas of Fort Greene without public housing increased by $44.7 \%$ in the $1980 \mathrm{~s}$ and an additional $12.9 \%$ in the $1990 \mathrm{~s}$ (Fig. 10). Given that the apartments in many of the brownstones were not rent stabilized, rents in these buildings increased substantially, contributing to an exodus of existing residents (Ethnographic Research 1998).

The middle class of Fort Greene created a version of what Jürgen Habermas has termed as the bourgeois public sphere (Habermas 1991). In its idealized form, the public sphere is an arena under which individuals come together and engage in criticalrational debate of common affairs in an effort to influence political and social action. The black public sphere (Black Public Sphere Collective 1995) that emerged in Fort Greene during the 1980s was middle class in nature, and though conversant with the working class public sphere that it was replacing, it was different. Besides working class commercial establishments, people involved in the working class public sphere 


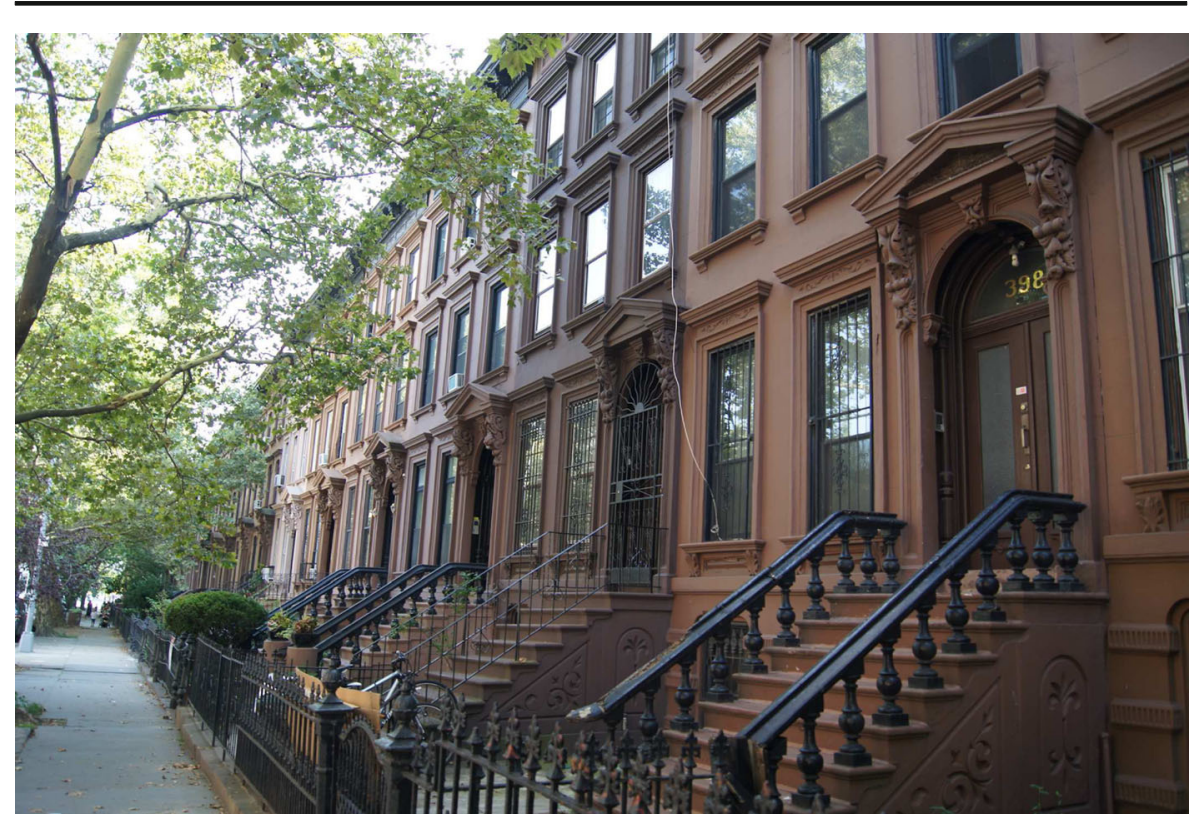

Fig. 9 Brownstones in Fort Greene. These brownstones have four stories. It is not uncommon to have more than one apartment in each floor. Source: Photo taken by the author, 2014

came together in streets, parks, and other public spaces. The individuals involved in the middle class public sphere came together mostly indoors. Middle class members of Fort Greene formed or took over civic associations, church groups, block associations, political organizations, and other entities in an effort to improve the neighborhood and address its social, political, and infrastructural problems. While many of these

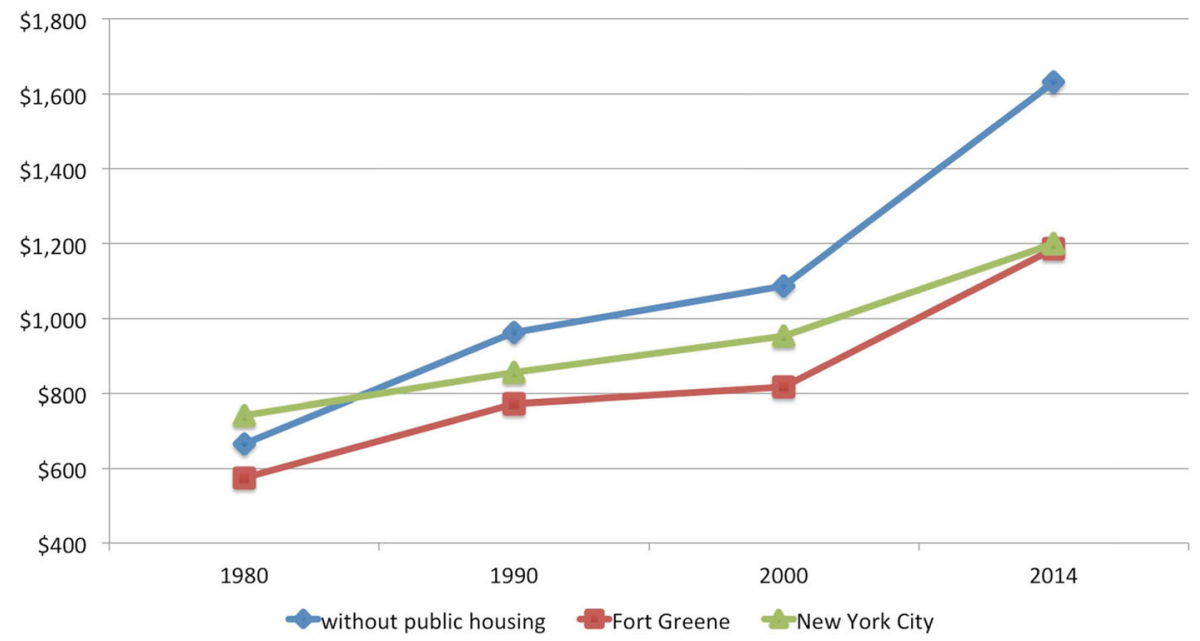

Fig. 10 Median gross rent in Fort Greene, the area of Fort Greene without public housing, and in New York City, 1980-2014. Source: U.S. Census Bureau Surveys, 1980-2000, and the Five-Year American Community Survey, 2014 
organizations remained concerned with the future of low-income people in Fort Greene, their interventions were sometimes resented because they resembled paternalism (Ethnographic Research 1998, 2005). Moreover, there were divisions between the lowincome people of Fort Greene who lived in public housing and the middle class people living in other parts of the neighborhood, and these divisions were exemplified in the separation and quality of schools (Anderson 2012).

By the early 1990s, Fort Greene and Clinton Hill were viewed as locations of a national black renaissance. Essence magazine ran a special section on Brooklyn calling it "the New Black Mecca" in 1991. The articles covered many neighborhoods of black Brooklyn, though Fort Greene and adjacent Clinton Hill received disproportionate attention. Elsie B. Washington wrote the following:

Living in Brooklyn's Fort Greene-Clinton Hill neighborhood means being in the embrace of all the energy, warmth and creativity of the Black diaspora. Here African American, Caribbean and African influences unite and inspire a community of folks who maintain beautiful Afrocentric homes on peaceful tree-lined streets, who build businesses that consciously support Black suppliers and artisans and who come together at neighborhood restaurants like the Greene Avenue Grill and Two Steps Down or at author readings at nearby Nkiru Books or at artist openings, with jazz, at Spiral Gallery. These are some of the places I visit for good food and drink, for excellent shopping and stimulating conversation - or for the warm welcome extended at shops such as V. J. Jones and Status (which has fab-u-lous one-of-a-kind hats, jewelry and wardrobe pieces, some of them made right there in the shop) (Washington 1991, p. 96).

Fort Greene and Clinton Hill were viewed as areas experiencing a cultural renaissance, as epicenters of black fashion and entertainment, and as meccas for black artists and entrepreneurs. By this time, new businesses such as boutiques, antique shops, fashionable restaurants, bars, and coffee shops, as well as specialty clothing manufacturers dotted the area. A year later, another article entitled "A culture explosion in Fort Greene," was published in Entertainment Weekly. The authors argued that hip commercial establishments in Fort Greene were dominated by the images and sounds of black America and were frequented by celebrities such as Spike Lee, Wesley Snipes, Branford Marsalis, and Chris Rock (Watkins and Appelo 1992). In fact, Fort Greene and its surroundings have been the home of Chris Rock, Branford Marsalis, Wesley Snipes, Lorna Simpson, Vernon Reid, Rosie Perez, Lawrence Fishburne, Terence Howard, Ol' Dirty Bastard, Erykah Badu, Gil Scott-Heron, Nelson George, Colson Whitehead, Mos Def, and Talib Kweli (Murphy 2013).

Sensing that the publicity that the neighborhood was receiving may end up displacing them, in 1992, small business owners of Fort Greene formed the Bogolan Merchant Association. Besides organizing to receive better rent prices from landlords, these merchants also tried to influence planning and development strategies undertaken by government bodies without consulting Fort Greene store keepers (Sutton 2010). In its heyday in the 1990s, Bogolan beautified the area, marketed the cultural distinctiveness of Fort Greene and Clinton Hill, branded the western part of black Brooklyn as a black cultural epicenter, and received recognition by government agencies. However, Bogolan always had to reconcile its belief in the free market with efforts to protect 
existing merchants from displacement. New entrepreneurs that opened stores in the late 1990s did not necessarily share the concerns of older shop owners, though Bogolan continued to function as the commercial arm of the area (Sutton 2010).

The black middle class public sphere flourished, not only in civic associations and private homes but also in bars, coffee shops, restaurants, bookstores, and other commercial establishments in late twentieth-century Fort Greene. Discussions about common affairs, investment strategies, job opportunities, as well as books and authors that working class people had never heard about, abounded. Some of the topics that elicited intense discussions and were remembered by residents of Fort Greene included the presidential campaigns of Jesse Jackson, the Cosby Show, the Iran-Contra hearings, the movies of Spike Lee, the influence and content of hip hop, the election and mayoralty of David N. Dinkins, the troubles of Marion Barry, the nomination of Clarence Thomas to the U.S. Supreme Court, Rodney King and the Los Angeles Riots, the trial of O.J. Simpson, and the success of Oprah Winfrey (Ethnographic Research 1998, 2005). A black middle class public sphere bourgeoned in late twentieth-century Fort Greene in ways that by the mid-2000s when I made a new round of interviews, it was remembered with nostalgia (Ethnographic Research 2005). The decline of this public sphere was a symptom of a decline of the black middle class world that formed and thrived in Fort Greene.

In Fort Greene, things began to change in the mid-1990s, though this was not obvious before the 2000s. Taking the office of the mayor in 1994, Rudolph Giuliani and his police commissioners became the architects of the orderly city (Chronopoulos 2011a). The New York Police Department (NYPD) was enlarged and restructured in an effort to reduce crime rates, which were already declining (Bowling 1999), and go after minor infractions (Greene 1999; McArdle and Erzen 2001). The idea was to establish a new social order in an effort to make affluent residents and visitors comfortable with the urban environment of various neighborhoods (Chronopoulos 2011a; Smith 1998, 2001).

The police activities of the Giuliani period were radically different from what was happening before. A middle class individual who moved to Fort Greene in 1979 told me that in the early 1980 s she called the police to report that there was prostitution in her street. To her surprise, the 911 operator told her that this was not an emergency and to stop calling them. Such stories were common in Fort Greene before the mid-1990s. In fact, residents developed strategies over what problems to report to the police and how to report them and this required a degree of tolerance over illegal activities that the authorities were not interested in tackling (Ethnographic Research 1998). The sale and consumption of drugs went largely uninterrupted in the 1980s as the NYPD continued to be an inefficient organization. Parts of Brooklyn suffered immensely during the crack epidemic with the NYPD ignoring or unable to deal with crackhouses and open air markets (Soffer 2010). Under Giuliani, the NYPD became more proactive and besides driving the drug trade underground, it went after low income individuals, mostly of color, whose infractions were minimal and part of everyday life (Chronopoulos 2011a; McArdle and Erzen 2001). For example, homeless people were ticketed and arrested for being in the wrong place at the wrong time and failing to follow orders (Vitale 2008).

The orderly city that emerged in the mid-1990s and was promoted by the city administration influenced the relocation of new groups of people who would previously not consider living in Fort Greene or other parts of black Brooklyn. The majority of these people were white. Unlike previous generations of whites who abandoned black 
and Latino spaces in the city, these groups did not mind living in minority neighborhoods as long as they felt safe and could find decent housing stock. Many of these people were pushed from more expensive parts of Manhattan and Brooklyn. Others could no longer obtain housing that suited their budget in other parts of the city and Fort Greene with its proximity to public transportation and other cultural amenities became a prime attraction. These groups of people were more affluent and less radical than previous generations of white gentrifiers who had moved to SOHO, the Lower East Side, or Williamsburg (Campo 2013; Chronopoulos 2013; Patterson 2007; Zukin 1982; Ethnographic Research 1998, 2005, 2011).

In 2005, a black software programmer from Fort Greene told me that in the mid-1990s, there was a man on crack hanging out near the Lafayette Street subway stop. His behavior became increasingly erratic, and though he was not dangerous, local people wished that he went away. One day, this man disappeared possibly because of the police, which had been trying to make the subway station and its environs more orderly. The programmer was elated about the disappearance of the "crackhead," but a few weeks later, he changed his mind. Witnessing the larger numbers of white people moving to Fort Greene and the way that they replaced black families, the programmer thought that this man by the Lafayette Street subway stop must have dissuaded some white people from moving there (Ethnographic Research 2005). Whether such unpleasant experiences are necessary in order to prevent the replacement or displacement of black people may be subject to debate. The effect that this man on crack had on white newcomers is also questionable and the programmer understood it. However, the outlook expressed by the programmer was not very different from that of other black people in Fort Greene. One local resident was annoyed that she spent a quarter of a century being rebuffed by people whenever she told them that Fort Greene was a great neighborhood, only to see the image of the area rehabilitated because of the influx of white people there. Others were not as annoyed because the bad image of Fort Greene prevented the influx of affluent whites and the making of an even more expensive neighborhood (Ethnographic Research 2005, 2011).

In the 1980s, the percentage of whites in the area of Fort Greene without public housing increased by $6 \%$; in the 1990 s, it increased by an additional $26.2 \%$ (Fig. 11). The movement of the 1990s was noticeable given that most whites relocated to Fort Greene in the latter part of the decade. The percentage of blacks declined by $4.7 \%$ in the 1990s. In terms of actual numbers, 749 blacks left Fort Greene in the 1990s while 780 whites moved into the neighborhood. The percentage of Latinos decreased by $16.4 \%$ in the $1990 \mathrm{~s}$, while there was also a small increase of Asians. The stagnation and decline in the numbers of Latinos is attributed to the fact that Fort Greene had become a middle class neighborhood since the late 1970s and not affordable to many low-income newcomers. Otherwise, the numbers of Latinos grew substantially in New York City during the same period.

\section{The Whitening of Fort Greene}

In 2009, Nelson George wrote an article for the New York Times about his recent experiences in Fort Greene, the neighborhood where he has lived since 1985: 


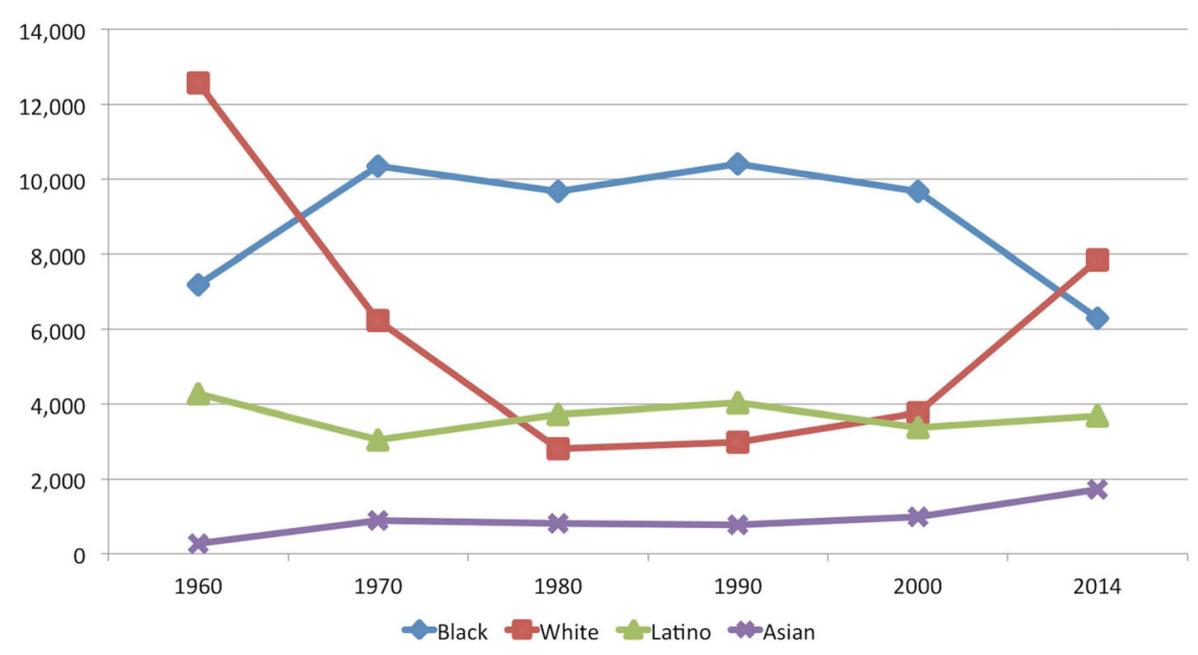

Fig. 11 Racial and ethnic groups in the Fort Greene areas without public housing, 1960-2014. Source: U.S. Census Bureau Surveys, 1960-2000, and the Five-Year American Community Survey, 2014

I used to look at the older white residents of ethnically changing Brooklyn enclaves like Canarsie and East Flatbush and wonder how they felt strolling through their neighborhood. Now I feel their sense of loss, their memories, their fear of the future. On Fulton Street on this particular Saturday, I watched workmen make preparations for a new Turkish restaurant as I stood in front of Silver Spoon, a recently opened yogurt ice cream shop on Fulton Street, on the site of a now departed Ethiopian restaurant that, I must admit, I visited only twice in my many years in Fort Greene. (So much for racial solidarity.) The Brooklyn Moon Cafe on Fulton, once the center of the New York spoken-word scene, continues on. Night of the Cookers, a long- established black oriented bar and restaurant on Fulton, is still in business. But there seems to be surprisingly little interplay between the new white Fort Greene and the old-school black community. I asked my friend Mike Thompson, who opened the Brooklyn Moon 15 years ago, about this. He said that while he did have white customers, he noticed that the newcomers seemed more comfortable at recently opened spots like a French bistro farther down on Fulton Street. Heading across South Portland Avenue toward Fort Greene Park, I got that "Oooh, tall, scary black man" look from a white woman as she passed me with averted eyes. This usually doesn't irritate me in Manhattan, where I expect it, but on this day, the look annoyed me coming from someone I imagine moved to the area maybe two weeks ago (George 2009).

Accounts such as those of George about a disappearing black Fort Greene are common. Long-term residents who persevered during the difficult years of government neglect and private disinvestment and helped to rebuild the neighborhood are especially lamenting the disappearance of a cultural and commercial infrastructure that has served them well (Ethnographic Research 2011). And while one could argue that small 
businesses and cultural institutions come and go and that a stagnant neighborhood is far from ideal, the changes that Fort Greene has undergone since 2003 are intense.

When it comes to demographics, in the area of Fort Greene without public housing, the percentage of whites increased by $113.8 \%$ in the 2000-2014 period, surpassing that of blacks, which declined by $35 \%$ (Fig. 11). When public housing is included, blacks still represent the numerical majority of Fort Greene, though the trend is similar to the area without public housing (Fig. 4). Fort Greene is becoming a majority white neighborhood for the first time in more than half a century.

If not for public and subsidized housing, the percentage of middle- and upperincome whites would have been much higher in Fort Greene. The Whitman and Ingersoll Houses (Fig. 12) have 3438 public housing units occupied by low-income people. There are also 1158 housing units that receive various government subsidies and are earmarked for low- and moderate-income people (Fig. 3). The great majority of these people are blacks and Latinos. This means that $38.1 \%$ of total occupied housing in Fort Greene is for people who could not afford market-rate housing anywhere near downtown Brooklyn. Whites usually move to the rest of the housing in Fort Greene and this includes rent-stabilized apartments, which have become costly enough to prevent moderate- and low-income newcomers from moving there. The public and subsidized housing units promise that the neighborhood will become more integrated racially. However, in recent years, racial integration in American cities usually occurs when whites move to a minority neighborhood, not the other way around.

In interviews with landlords and people working in real estate companies, the explanation about the large influx of whites was the following. In the 1990s, the majority of people seeking to buy properties or rent apartments in Fort Greene and Clinton Hill were black. Toward the late 1990s, the percentage of whites increased

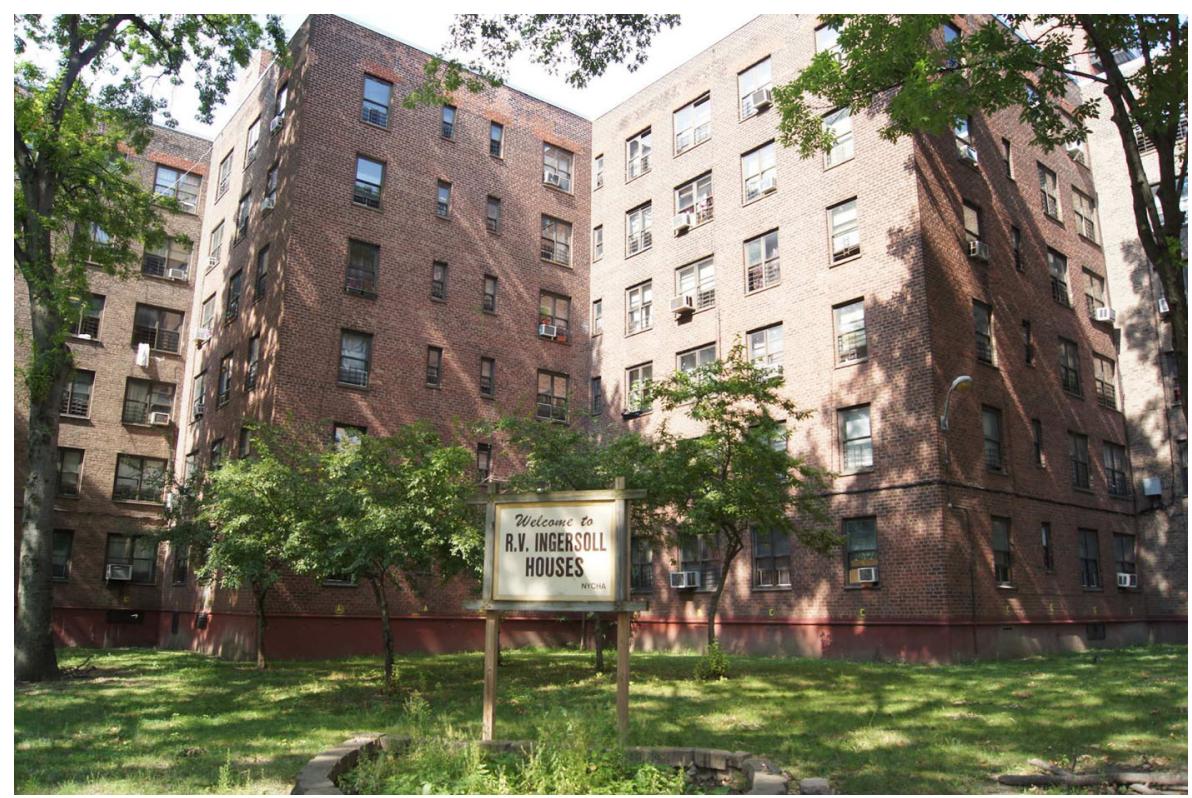

Fig. 12 The Ingersoll Houses, one of two sizable public housing developments in Fort Greene. Source: Photo taken by the author, 2014 
substantially, though blacks were more likely to move to Fort Greene. Many whites were still reluctant. After the World Trade Center attacks in 2001, demand slowed down. However, from 2003 until 2008, the real estate market of New York made a resounding comeback and overheated. During this period, whites seeking housing in Fort Greene (and Clinton Hill) greatly outnumbered blacks. Whites outbid blacks and each other in purchasing properties and were able to commit in renting apartments faster. The people who were replaced were usually black. Many African Americans retired, sold their houses, and relocated. Younger black people began to move to other parts of Brooklyn that were more affordable, and as time went on, they were excluded from Fort Greene. Some blacks were also displaced from unregulated rental properties when landlords increased rents considerably (Ethnographic Research 2011). This trend slowed down during the Great Recession, but began to pick up again after 2010.

Changes in the commercial and cultural infrastructure of the area mirror the demographic changes. According the Stacey Sutton (2015), in the first decade of the twenty-first century, approximately $75 \%$ of black stores in Fort Greene closed. There are many reasons why these businesses shut down, though in most cases, gentrification pressures undermined their existence while new black entrepreneurs did not have the connections with investors willing to support their ventures. Many stores closed because landlords offered unaffordable rents to renew commercial leases and preferred new commercial establishments with multiple investors willing to pay large sums of money for many years. However, even the very small percentage of business owners who owned the building where their store was located was affected; gentrification meant that they could make significantly more money by renting to others rather than continuing to operate their business. These business owners worried about the decline in the numbers of black people in Fort Greene and were uncertain about the tastes and preferences of the white newcomers. Finally, pressures by city agencies expedited this decision to close (Ethnographic Research 2011).

Between 2002 and 2013, the city administration under Mayor Michael Bloomberg accelerated the neoliberal urbanization of New York City. The regulatory apparatus of the city government was used toward this end, disproportionately targeting small businesses especially the ones located in the outer boroughs and in gentrifying areas (de Blasio 2013). City agencies such as the Departments of Health and Mental Hygiene, Consumer Affairs, Sanitation, Transportation, Buildings, and others were reorganized and involved in increased inspections and ticket blitzes. In Fort Greene, merchants complained that these inspections represented nothing more than harassment and increased revenue for the city (Sutton 2015). They also complained that administrative and other judges did not properly do their job or use their discretion whenever they challenged the tickets. Merchants who hired lawyers had a better chance of receiving proper attention from the courts, but this cost even more money (Ethnographic Research 2011). Gradually, continuous ticketing made the running of businesses more expensive; especially, mom and pop stores were forced to give up (Sutton 2015). In that sense, the closure of these businesses was not due to a natural process of commercial turnover but expedited and forced by the city government and the private sector.

The nature of gentrifying agents in Fort Greene changed as follows. Between the late 1960s and 2003, gentrification was a bottom-up process with mostly black middle- and upper-middle class people buying or renting in Fort Greene. The majority of apartment building owners and commercial spaces where white while the majority of homeowners were black. Still, most people living or operating businesses in Fort Greene were black, 
and while gentrification determined who could live in large parts of the neighborhood, big corporations and real estate interests were not involved in the production of space. This changed from 2003 onward, not because of development inside Fort Greene most of which is a historic district, but because of development pressures in its margins (Fig. 13). For example, a controversial public-private partnership called the Atlantic Yards development project involves the Empire State Development Corporation and Forest City Ratner Companies. Besides an already completed basketball arena for the Brooklyn Nets called Barclays Center, (Fig. 14) the project intends to build 16 residential and mixed-use towers (Lavine and Oder 2010; Thompson 2011). Intense development activity has been taking place in most of downtown Brooklyn, threatening even lucrative commercial areas such as Fulton Mall (Sutton 2015; Woo et al. 2010). While most of these projects are taking place in land immediately outside of Fort Greene, their immensity is affecting the residential and commercial character of the neighborhood. Apartment buildings and commercial spaces inside Fort Greene are sold to new operators who are predicting high profits once existing tenants move out. Investors are backing new commercial establishments, expecting a large number of customers from the new residential buildings, the basketball arena, and downtown Brooklyn (Ethnographic Research 2011).

\section{Conclusion}

Spike Lee's outburst against white gentrification in 2014 reflected the new racial and ethnic trends of Fort Greene in the first decade of the twenty-first century. It took only 12 years for a neighborhood that has been majority black since the

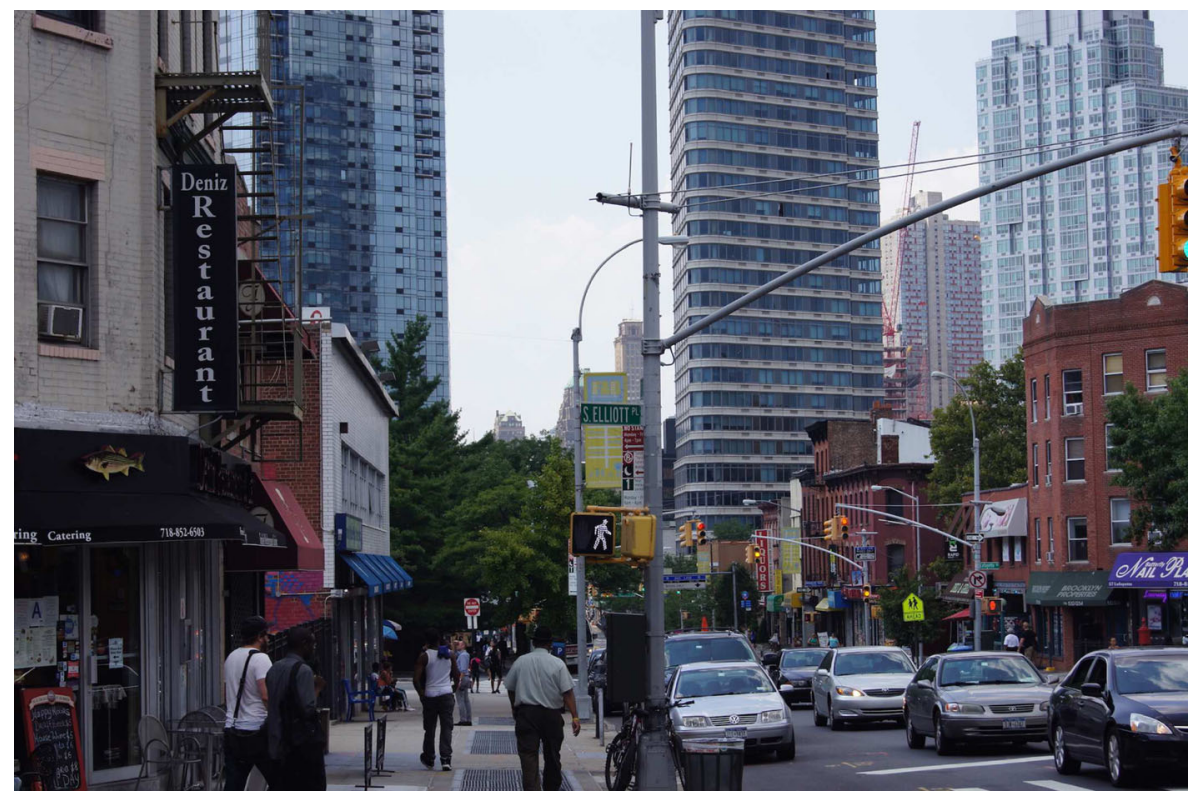

Fig. 13 High-rises built right outside the boundaries of Fort Greene. According to planning documents and proposals, more such buildings are going to be developed in the next few years in locations immediately west and south of Fort Greene. Source: Photo taken by the author, 2014 


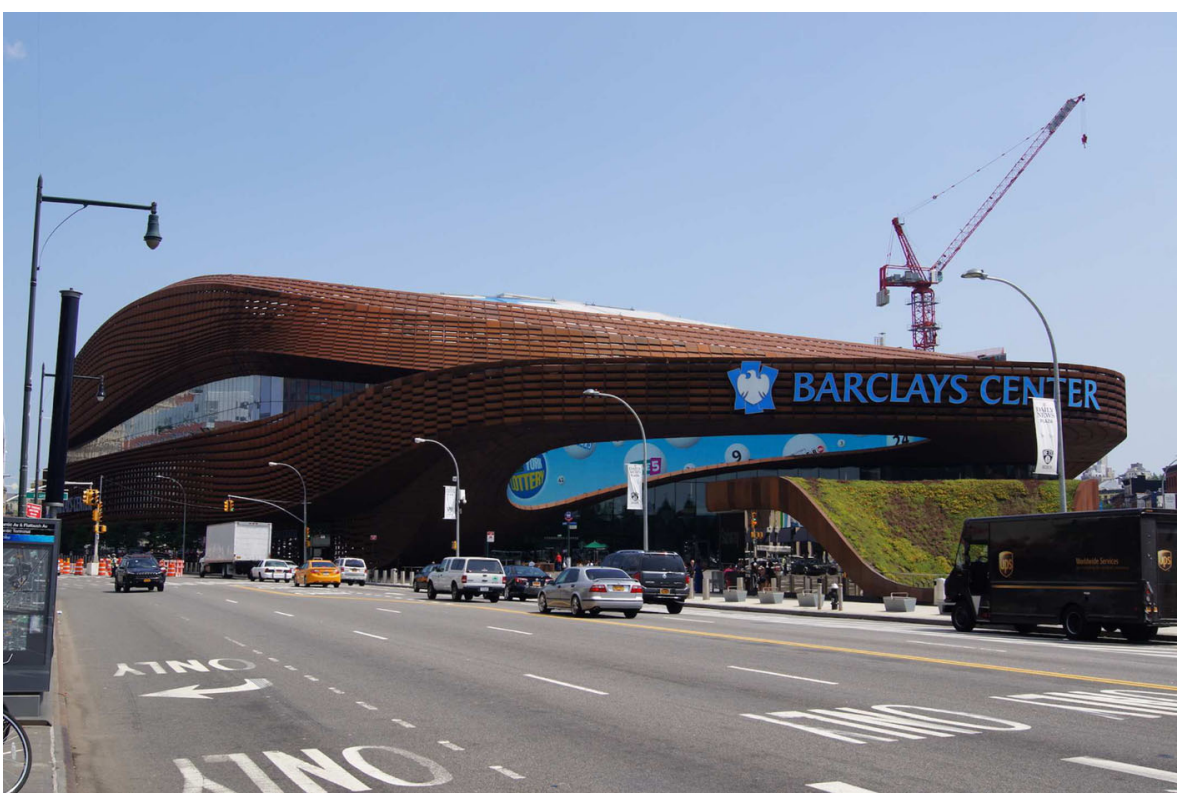

Fig. 14 The Barclays Center. Source: Photo taken by the author, 2014

1960s to become almost white (Figs. 4 and 11). Gentrification is the main cause for this racial transformation and whites have been directly replacing or displacing blacks. Along with the demographic changes, the cultural and commercial infrastructure of Fort Greene is also changing not because existing businesses serving mostly African Americans were not successful, but because of neoliberal urbanization; the public and private sectors are seeking higher profits that can be obtained through a new and more intensified regime of profitable land use and commercial exploitation.

It is not easy to find black neighborhoods in the USA becoming white as rapidly as Fort Greene. To be sure, many black neighborhoods in several urban locations of the USA have seen a large influx of Latinos (Sharkey 2013), but these changes reflect the demographic trends of these locales and have little to do with gentrification. In New York City, the percentage of whites has been declining for most of the post-1945 period. However, in Fort Greene and other gentrifying neighborhoods, the numbers of whites are increasing. The percentage of blacks in New York has declined in recent years, though that decline is not as significant. On the other hand, the decline of the black population in Fort Greene is alarming (Figs. 4 and 11).

Scholars have argued that it is usually the black middle class that gentrifies black neighborhoods (Boyd 2005, 2008; Hyra 2008; Jackson 2001; Moore 2005, 2009; Pattillo 2007; Taylor 1992, 2002); however, in Fort Greene, this has changed with whites overwhelmingly representing the new gentrifying agents. ${ }^{3}$ Fort Greene has been attractive to middle- and upper-class whites because it has been middle class for a long period of time, because it is located right next to downtown Brooklyn with numerous

\footnotetext{
${ }^{3}$ Many of the black neighborhoods of Washington, DC, are experiencing a similar racial turnover, though the process has been longer there and it is not identical to that of New York.
} 
transportation lines and a desirable commercial infrastructure, because western and northern Brooklyn have become among the most desirable sections of New York, and the built environment of Fort Greene is attractive. More than this, the city and state governments have facilitated this neighborhood change with controversial and possibly corrupt urban development projects such as the Atlantic Yards and with punitive inspections of small black businesses. These projects and policies are promoted as race-neutral. However, when blacks are mostly replaced or displaced and whites become the new tenants of the residential and commercial spaces of the neighborhood, this idea of race-neutrality is embarrassing.

One could argue that the erosion of the black spatial imaginary of Fort Greene undermined its ability to resist white gentrification. However, even in Central Harlem and other black neighborhoods, this idea of self-help and community control declined. In many cases, a more moderate version of community control allowed the rebuilding of these areas with subsidized housing that became the home of low- and moderate-income blacks. This did not work out as well in Fort Greene, because it became middle class early on and before the city government decided to rebuild black and Latino neighborhoods. To be sure, the middle class transformation of Fort Greene allowed highly educated blacks with high paying jobs to create a home in New York. The problem is that in the long run the structure of inequality that defines the USA manifested itself spatially in Fort Greene and this undermined the blackness of the neighborhood.

Fort Greene may be one of the first black urban neighborhoods in the USA becoming white. However, in the foreseeable future, more of these neighborhoods will attract large numbers of white people. Racial integration can be one of the most desirable outcomes of neighborhood change, but not when a capital class empowered by inequality has the ability to extract high rents and to displace or replace existing tenants.

\section{Compliance with Ethical Standards}

Funding This study received no funding.

Conflict of Interest The author declares that he has no conflict of interest.

Open Access This article is distributed under the terms of the Creative Commons Attribution 4.0 International License (http://creativecommons.org/licenses/by/4.0/), which permits unrestricted use, distribution, and reproduction in any medium, provided you give appropriate credit to the original author(s) and the source, provide a link to the Creative Commons license, and indicate if changes were made.

\section{References}

Aalbers, M. B. (2011). The revanchist renewal of yesterday's city of tomorrow. Antipode, 43(5), 1696-1724. Anderson, N. S. (2012). Hood politics: charter schools, race and gentrification in Fort Greene. In J. N. DeSena \& T. Shortell (Eds.), The world in Brooklyn: gentrification, immigration, and ethnic politics in a global city (pp. 363-378). Lanham: Lexington Books.

Angotti, T. (2008). New York for sale: community planning confronts global real estate. Cambridge: Massachusetts Institute of Technology Press. 
Asch, C. M., \& Musgrove, G. D. (2016). "We are headed for some bad trouble": gentrification and displacement in Washington, DC, 1920-2014. In D. Hyra \& S. Prince (Eds.), Capital dilemma: growth and inequality in Washington, DC. New York: Routledge.

Black Public Sphere Collective. (1995). The black public sphere: a public culture book. Chicago: University of Chicago Press.

Bloom, N. D. (2008). Public housing that worked: New York in the twentieth century. Philadelphia: University of Pennsylvania Press.

Bonilla-Silva, E. (2006). Racism without racists: color-blind racism and the persistence of racial inequality in the United States. Lanham: Rowman \& Littlefield.

Bostic, R. W., \& Martin, R. W. (2003). Black home-owners as a gentrifying force? Neighbourhood dynamics in the context of minority home-ownership. Urban Studies, 40(12), 2427-2449.

Bowling, B. (1999). The rise and fall of New York murder: zero tolerance or crack's decline? British Journal of Criminology, 39(4), 531-554.

Boyd, M. (2005). The downside of racial uplift: meaning of gentrification in an African American neighborhood. City \& Society, 17(2), 265-288.

Boyd, M. (2008). Defensive development the role of racial conflict in gentrification. Urban Affairs Review, 43(6), 751-776.

Bridge, G. (2003). Time-space trajectories in provincial gentrification. Urban Studies, 40(12), 2545-2556.

Buntin, J. (2015). The myth of gentrification. Slate. http://www.slate.com/articles/news_and_ politics/politics/2015/01/the gentrification myth it s rare and not as bad for the poor as people. html. Accessed 8 May 2016

Byrne, J. P. (2002). Two cheers for gentrification. Howard Law Journal, 46(3), 405-432.

Campo, D. (2013). The accidental playground: Brooklyn waterfront narratives of the undesigned and unplanned. New York: Fordham University Press.

Caro, R. A. (1974). The power broker: Robert Moses and the decline of New York. New York: Alfred A. Knopf.

Chronopoulos, T. (2011a). Spatial regulation in New York City: from urban renewal to zero tolerance. New York: Routledge.

Chronopoulos, T. (2011b). Morality, social disorder, and the working class in Times Square, 1892-1954. Australasian Journal of American Studies, 30(1), 1-19.

Chronopoulos, T. (2013). The politics of race and class and the changing spatial fortunes of the McCarren pool in Brooklyn, New York, 1936-2010. Space and Culture, 16(1), 104-122.

Chronopoulos, T. (2014). Robert Moses and the visual dimension of physical disorder: efforts to demonstrate urban blight in the age of slum clearance. Journal of Planning History, 13(3), 207-233.

Connolly, H. X. (1977). A ghetto grows in Brooklyn. New York: New York University Press.

Coscarelli, J. (2014). Spike Lee's amazing rant against gentrification: “we been here!” New York. http://nymag. com/daily/intelligencer/2014/02/spike-lee-amazing-rant-against-gentrification.html\#. Accessed 28 April 2016

Curran, W. (1998). City policy and urban renewal: a case study of Fort Greene, Brooklyn. Middle States Geographer, 31, 71-82.

Davidson, J. (2014). Is gentrification all bad? New York, 47(3), 36-75.

de Blasio, B. (2013). Borough bias: how the Bloomberg administration drains outer borough businesses. New York: Public Advocate for the City of New York.

DeGiovanni, F. (1984). Neighborhood revitalization in fort Greene and Clinton Hill. New York Affairs, 8(2), 86-104.

Delany, S. R. (1999). Times Square red, Times Square blue. New York: New York University Press.

Duany, A. (2001). Three cheers for gentrification. American Enterprise, 12(3), 36-39.

Freeman, I. H. (1958, November 19). Brooklyn slums shock officials. New York Times, p. 31.

Freeman, L. (2005). Displacement or succession? Residential mobility in gentrifying neighborhoods. Urban Affairs Review, 40(4), 463-491.

Freeman, L. (2006). There goes the hood: views of gentrification from the ground up. Philadelphia: Temple University Press.

Freeman, L. (2009). Neighbourhood diversity, metropolitan segregation and gentrification: what are the links in the US? Urban Studies, 46(10), 2079-2101.

Freeman, L., \& Braconi, F. (2004). Gentrification and displacement. Journal of the American Planning Association, 70(1), 39-52.

Freund, D. M. P. (2007). Colored property: state policy and white racial politics in suburban America. Chicago: University of Chicago Press.

Fried, J. P. (1966, February 6). A historic area seeks to survive. New York Times, p. R1

George, N. (2009, April 5). Strangers on his street. New York Times, p. CY3 
Greene, J. A. (1999). Zero tolerance: a case study of police policies and practices in New York City. Crime and Delinquency, 45(2), 171-187.

Habenstreit, B. (1974). Fort Green U.S.A. Indianapolis: Bobbs-Merrill Company.

Habermas, J. (1991). The structural transformation of the public sphere: an inquiry into a category of bourgeois society. Cambridge: Massachusetts Institute of Technology Press.

Hampson, R. (2005, April 19). Studies: gentrification a boost for everyone. USA Today

Heck, A. (2016). A tale of two theatres: the implications of redevelopment and gentrification on community anchors and identity in U Street/Shaw. In D. Hyra \& S. Prince (Eds.), Capital dilemma: growth and inequality in Washington, DC. New York: Routledge.

Hoffman, L. M. (2003). The marketing of diversity in the inner city: tourism and regulation in Harlem. International Journal of Urban and Regional Research, 27(2), 286-299.

Howell, K. (2016). "It's complicated...": long-term residents and their relationships to gentrification in Washington, DC. In D. Hyra \& S. Prince (Eds.), Capital dilemma: growth and inequality in Washington, DC. New York: Routledge.

Hyra, D. (2008). The new urban renewal: the economic transformation of Harlem and Bronzeville. Chicago: University of Chicago Press.

Hyra, D. (2015). The back-to-the-city movement: neighbourhood redevelopment and processes of political and cultural displacement. Urban Studies, 52(10), 1753-1773.

Hyra, D., \& Prince, S. (Eds.). (2016). Capital dilemma: growth and inequality in Washington, DC. New York: Routledge.

Jackson, J. L., Jr. (2001). Harlemworld: doing race and class in contemporary Black America. Chicago: University of Chicago Press.

Kim, C. J. (2000). Bitter fruit: the politics of black-Korean conflict in New York City. New Haven: Yale University Press.

Lavine, A., \& Oder, N. (2010). Urban redevelopment policy, judicial deference to unaccountable agencies, and reality in Brooklyn's Atlantic yards project. The Urban Lawyer, 42(2), 287-373.

Lees, L., Slater, T., \& Wyly, E. (2007). Gentrification. New York: Routledge.

Lipsitz, G. (2006). The possessive investment in whiteness: how white people profit from identity politics. Philadelphia: Temple University Press.

Lipsitz, G. (2011). How racism takes place. Philadelphia: Temple University Press.

Marcuse, P. (1985). Gentrification, abandonment, and displacement: connections, causes, and policy responses in New York City. Journal of Urban and Contemporary Law, 28, 195-240.

McArdle, A., \& Erzen, T. (2001). Zero tolerance: quality of life and the new police brutality in New York City. New York: New York University Press.

Moore, K. S. (2005). What's class got to do with it? Community development and racial identity. Journal of Urban Affairs, 27(4), 437-451.

Moore, K. S. (2009). Gentrification in black face?: the return of the black middle class to urban neighborhoods. Urban Geography, 30(2), 118-142.

Murphy, B. M. (2013). The Fort Greene Renaissances. Kenyon Review. http://www.kenyonreview.org/2013/12 /fort-greene-renaissances/. Accessed 5 May 2016

Murphy, D. (2014, February 27). B'klyn gentrifiers respond to Spike tirade: YOU WHINER. New York Daily News

Nevius, C. W. (2013). Gentrification no longer a dirty word. San Francisco Chronicle. Accessed 15 March 2016

New York Times. (1953, July 13). Moses plans doom of Brooklyn slum. New York Times, p. 1

New York City Landmarks Preservation Commission. (1978). Fort Greene historic district: designation report. New York: The Commission.

Osman, S. (2011). The invention of brownstone Brooklyn: gentrification and the search for authenticity in postwar New York. New York: Oxford University Press.

Patterson, C. (2007). Resistance: a radical political and social history of the Lower East Side. New York: Seven Stories Press.

Pattillo, M. (2005). Black middle-class neighborhoods. Annual Review of Sociology, 31, 305-329.

Pattillo, M. (2007). Black on the block: the politics of race and class in the city. Chicago: University of Chicago Press.

Podair, J. E. (2008). The strike that changed New York: blacks, whites, and the Ocean Hill-Brownsville crisis. New Haven: Yale University Press.

Prince, S. (2002). Changing places: race, class, and belonging in the "New" Harlem. Urban Anthropology and Studies of Cultural Systems and World Economic Development, 31(1), 5-35.

Prince, S. (2005). Race, class, and the packaging of Harlem. Identities: Global Studies in Culture and Power, 12(3), 385-404. 
Pritchett, W. E. (2002). Brownsville, Brooklyn: blacks, Jews, and the changing face of the ghetto. Chicago: University of Chicago Press.

Purnell, B. (2013). Fighting Jim Crow in the County of Kings: the congress of racial equality in Brooklyn. Lexington: University Press of Kentucky.

Reichl, A. J. (1999). Reconstructing Times Square: politics and culture in urban development. Lawrence: University Press of Kansas.

Rosenberg, J. (1998). Fort Greene, New York. Cityscape: A Journal of Policy Development and Research, 4(2), 179-195.

Schaffer, R., \& Smith, N. (1986). The gentrification of Harlem? Annals of the Association of American Geographers, 76(3), 347-365.

Schwartz, J. (1993). The New York approach: Robert Moses, urban liberals, and redevelopment of the inner city. Columbus: Ohio State University Press.

Sharkey, P. (2013). Stuck in place: urban neighborhoods and the end of progress toward racial equality. Chicago: University of Chicago Press.

Slater, T. (2006). The eviction of critical perspectives from gentrification research. International Journal of Urban and Regional Research, 30(4), 737-757.

Slater, T. (2009). Missing Marcuse: on gentrification and displacement. City, 13(2-3), 292-311.

Smith, N. (1996). The new urban frontier: gentrification and the revanchist city. New York: Routledge.

Smith, N. (1998). Giuliani time: the revanchist 1990s. Social Text, 57, 1-20.

Smith, N. (2001). Global social cleansing: postliberal revanchism and the export of zero tolerance. Social Justice, 28(3), 68-74.

Soffer, J. (2010). Ed Koch and the rebuilding of New York City. New York: Columbia University Press.

Spain, D. (1980). Black-to-white successions in central-city housing limited evidence of urban revitalization. Urban Affairs Review, 15(4), 381-396.

Stabrowski, F. (2014). New-build gentrification and the everyday displacement of polish immigrant tenants in Greenpoint, Brooklyn. Antipode, 46(3), 794-815.

Sugrue, T. J. (1996). The origins of the urban crisis: race and inequality in postwar Detroit: race and inequality in postwar Detroit. Princeton: Princeton University Press.

Sullivan, L. (2014). Gentrification may actually be boon to longtime residents. NPR.org. http://www.npr. org/2014/01/22/264528139/long-a-dirty-word-gentrification-may-be-losing-its-stigma. Accessed 8 June 2016

Sutton, S. A. (2010). Rethinking commercial revitalization: a neighborhood small business perspective. Economic Development Quarterly, 24(4), 352-371.

Sutton, S. A. (2015). The spatial politics of black business closure in central Brooklyn. In M. Bay \& A. Fabian (Eds.), Race and retail: consumption across the color line (pp. 200-221). New Brunswick: Rutgers University Press.

Taylor, M. M. (1992). Can you go home again? Black gentrification and the dilemma of difference. Berkeley Journal of Sociology, 37, 101-128.

Taylor, C. (1994). The black churches of Brooklyn. New York: Columbia University Press.

Taylor, C. (1997). Knocking at our own door: Milton A. Galamison and the struggle to integrate New York City schools. New York: Columbia University Press.

Taylor, M. M. (2002). Harlem: between heaven and hell. Minneapolis: University of Minnesota Press.

Thabit, W. (2003). How east New York became a ghetto. New York: New York University Press.

Thompson, J. P. (2006). Double trouble: black mayors, black communities, and the call for a deep democracy. New York: Oxford University Press.

Thompson, C. (2011). Discourses of community contestation: the fight over the Atlantic Yards in Brooklyn, New York. Urban Geography, 32(8), 1189-1207.

Van Criekingen, M., \& Decroly, J.-M. (2003). Revisiting the diversity of gentrification: neighbourhood renewal processes in Brussels and Montreal. Urban Studies, 40(12), 2451-2468.

Vigdor, J. L. (2002). Does gentrification harm the poor? Brookings-Wharton Papers on Urban Affairs, 133-173

Vitale, A. S. (2008). City of disorder: how the quality of life campaign transformed New York politics. New York: New York University Press.

Washington, E. B. (1991). The happening 'hood. Essence, 22(6), 96-98.

Watkins, M., \& Appelo, T. (1992). A culture explosion in Fort Greene. Entertainment Weekly. http://www.ew. com/article/1992/05/15/culture-explosion-fort-greene. Accessed 19 March 2016

Weisman, S. R. (1971). Brooklyn renewal: urban Cinderella? New York Times, p. Q83

Wilder, C. S. (2000). A covenant with color: race and social power in Brooklyn 1636-1990. New York: Columbia University Press.

Williams, B. (1988). Upscaling downtown: stalled gentrification in Washington. Ithaca: Cornell University Press. 
Wilson, F. (1992). Gentrification and neighborhood dislocation in Washington, DC: the case of black residents in central area neighborhoods. Research in Urban Sociology, 2, 113-143.

Woo, R., TenHoor, M., \& Rich, D. (2010). Street value: shopping, planning, and politics at Fulton mall. New York: Princeton Architectural Press.

Woodsworth, M. (2016). Battle for Bed-Stuy: the long war on poverty in New York City. Cambridge: Harvard University Press.

Zipp, S. (2010). Manhattan projects: the rise and fall of urban renewal in Cold War New York. New York: Oxford University Press.

Zukin, S. (1982). Loft living: culture and capital in urban change. Baltimore: Johns Hopkins University Press.

Zukin, S., Trujillo, V., Frase, P., Jackson, D., Recuber, T., \& Walker, A. (2009). New retail capital and neighborhood change: boutiques and gentrification in New York City. City and Community, 8(1), 47-64. 